\title{
Técnicas constructivas mixtas en piedra en la Córdoba omeya
}

\section{Mixed constructive techniques in stone in umayyad Cordova}

\author{
Alberto León-Muñoz ${ }^{1}$ \\ Universidad de Córdoba
}

\begin{abstract}
RESUMEN
En este trabajo recopilamos un amplio repertorio de construcciones cordobesas en las que se emplean técnicas constructivas mixtas en piedra, desde época tardoantigua hasta el final d el Califato Omeya de al-Ándalus. Los tipos de aparejos identificados están, por lo general, vinculados c on construcciones públicas de carácter monumental. De este estudio se deduce el mantenimiento de estas técnicas como un recurso para reducir costes en la construcción de los grandes proyectos arquitectónicos, pero manteniendo el carácter prestigioso del empleo de la piedra como material edilicio básico.
\end{abstract}

Palabras clave: Córdoba; técnicas constructivas mixtas; tardoantigüedad; época emiral; época califal; opus africanum; damero.

\begin{abstract}
This work compiles a wide repertoire of constructions from Cordova, in which mixed constructive techniques in stone are used from the Late Antiquity to the end of the Umayyad Caliphate of al-Ándalus. The building procedures identified come from, generally, monumental public structures. This study shows the maintenance of these techniques as a resource to reduce costs in the construction of large architectural projects, as well as to maintain the prestigious use of stone as the main building material.
\end{abstract}

Key words: Cordova; mixed construction techniques; Late Antiquity; Emiral period; Caliphal period; Opus Africanum; checkerboard pattern.

Recibido: 18-04-2018. Aceptado: 17-05-2018. Publicado online: 27-12-2018

Cómo citar este artículo / Citation

León-Muñoz, A. 2018: "Técnicas constructivas mixtas en piedra en la Córdoba omeya", Arqueología de la Arquitectura, 15: e078. https://doi. org/10.3989/arq.arqt.2018.022

Copyright: (c) 2018 CSIC. Este es un artículo de acceso abierto distribuido bajo los términos de la licencia de uso y distribución Creative Commons Reconocimiento 4.0 Internacional (CC BY 4.0).

\section{INTRODUCCIÓN: LAS TÉCNICAS CONSTRUCTIVAS EN PIEDRA EN LA CÓRDOBA ANDALUSÍ}

Al tratar las técnicas constructivas andalusíes, resultan sobradamente conocidos los clásicos aparejos en sillería concertada con una alternancia regular de los bloques dispuestos a soga y tizón. Tal es así que se identifica como aparejo oficial o "real" andalusí (Azuar 1995: 131 y 2005), para el que se ha propuesto algún ensayo en el que se ha intentado marcar una evolución en los módulos de las piezas, sin que los resultados hayan sido nada concluyentes (Pavón 1994).

Sin embargo, las técnicas mixtas en piedra empleadas en las construcciones islámicas, en particular de época emiral, apenas han recibido una atención entre la comunidad científica. Y ello pese a que resulta un aspecto crucial para aproximarnos al interesante debate acerca de la continuidad o desaparición de las técnicas constructivas en piedra desde época clásica y tardoantigua y su posible recuperación a partir de la presencia islámica, que servirá como canal de transmisión de algunos

' aleonm@uco.es / ORCID iD: https://orcid.org/0000-0002-4516-0804 
procedimientos constructivos en la península ibérica (cfr. Caballero 2009; Caballero y Utrero 2005 y 2013).

En relación con esta cuestión ha resultado clave la excavación de algunos edificios singulares en Mérida; en concreto, los conocidos como "palacetes" islámicos en el área arqueológica de Morería, donde se ha identificado un amplio repertorio de técnicas y materiales constructivos de tradición romana y tardo-antiguas en edificios bien fechados entre finales del siglo VIII y principios del siglo IX ( $c f r$. Alba 2009: 410). La ubicación, diseño, potencia y características arquitectónicas de este conjunto de edificios hacen pensar en su vinculación directa con el poder cordobés, como espacios de representación de la nueva élite urbana que ejercerá el gobierno delegado en la ciudad emeritense.

Estos tipos de fábricas mixtas se vinculan tradicionalmente con el mundo clásico (Vargas Lorenzo 2016) o, a lo sumo, con construcciones de época tardoantigua ${ }^{2}$, pero no se han asociado con la etapa islámica, de nuevo, con la excepción del caso emeritense. Así, por ejemplo, la técnica conocida como "opus africanum" o de cadenas verticales de bloques de sillar se consideraba que "apenas se dio en la arquitectura hispanomusulmana" (Pavón 1994: 301).

Sin embargo, en la capital omeya andalusí las intervenciones arqueológicas desarrolladas en los últimos años han permitido documentar un significativo número de construcciones de diferente naturaleza y función, pero de una notable entidad arquitectónica, en las que se ha identificado un amplio muestrario de aparejos mixtos en piedra, la mayoría de los cuales permanecen inéditos, y que nos permiten profundizar en procedimientos técnicos que no han sido estudiados hasta el momento (Fig. 1). La cantidad de ejemplos documentados y los tipos de edificios en los que se emplean permiten plantear que, en realidad, se trata de técnicas más habituales y relevantes de lo considerado hasta ahora.

Pese a la lógica heterogeneidad de las técnicas -habida cuenta del empleo recurrente de material constructivo de acarreo, en especial, en los bloques de

El Proyecto de Investigación Técnicas constructivas y arquitectura del poder al noroeste de la Tarraconense. Metodología de representación y parámetros analíticos para la comprensión de procesos evolutivos entre el alto imperio y la antigüedad tardia ha permitido recopilar un significativo repertorio de edificios públicos con técnicas mixtas en ciudades tardoantiguas como Barcelona, Tarragona y Valencia, entre otras. Dicho proyecto se ha materializado, de momento, en la publicación de un volumen monográfico sobre técnicas constructivas en la revista QuarHis, $n^{\circ} 12,2016$. En el caso de Córdoba, se realizó una primera aproximación sobre algunos edificios tardoantiguos (León 2006). sillería que sirven de elementos portantes del muro-, se encuentran algunos rasgos comunes en muchas de ellas. Así, por ejemplo, la mayoría de los casos documentados parecen corresponder a obras oficiales o vinculadas al poder omeya o su entorno inmediato (infraestructura en el conjunto palatino, almunias, mezquitas, etc.). La definición de las características más frecuentes permitirá sentar las bases de cara a una futura sistematización de las técnicas constructivas cordobesas, para las que ya se ha hecho un primer intento con la sillería (León, en prensa). Estas aproximaciones deben realizarse, en primer término, en el ámbito local, pues es a esta escala donde son realmente eficaces. No obstante, teniendo en cuenta la condición de capital del Estado Omeya andalusí, este estudio permite vislumbrar un mayor potencial, ante la posibilidad de aplicar a otros enclaves peninsulares las conclusiones establecidas para Córdoba.

Nuestro objetivo de momento no es el establecimiento de una precisa cronotipología, pues uno de los principales problemas radica en la posibilidad de aquilatar las dataciones de los edificios que emplean estos recursos constructivos. Conscientes de la importancia de una correcta atribución cronológica, hemos intentado justificar la datación propuesta por los excavadores en cada uno de los ejemplos registrados, lo que no ha sido siempre posible. En estos casos, a falta de argumentos estratigráficos o materiales consistentes, hemos empleado el habitual procedimiento analógico-comparativo para plantear una hipótesis viable de datación.

Por otro lado, se trata de soluciones arquitectónicas que evidencian una continuidad de tradiciones técnicas precedentes desde época clásica, que perduran durante la Antigüedad tardía y la etapa islámica. En todos estos periodos se mantienen las características esenciales de las técnicas mixtas en piedra: la alternancia de bloques de sillería con rellenos intermedios de mampostería más o menos regular, con la intención de aprovechar los recursos disponibles, reutilizando material constructivo y optimizando el ahorro de costes en la construcción (Beltrán y Macías 2016: 33). Se plantea, pues, la cuestión de la perduración local frente a la innovación o transmisión foránea de estos procedimientos técnicos en la arquitectura andalusí. Es por esta razón que hemos incluido en nuestro catálogo los ejemplos documentados en la ciudad pertenecientes a la etapa tardoantigua, que muestran la existencia de un rico substrato arquitectónico previo. No obstante, se aprecia una evolución y perfeccionamiento de estos procedimientos constructivos en época omeya, con un mayor empleo de los morteros de cal, 


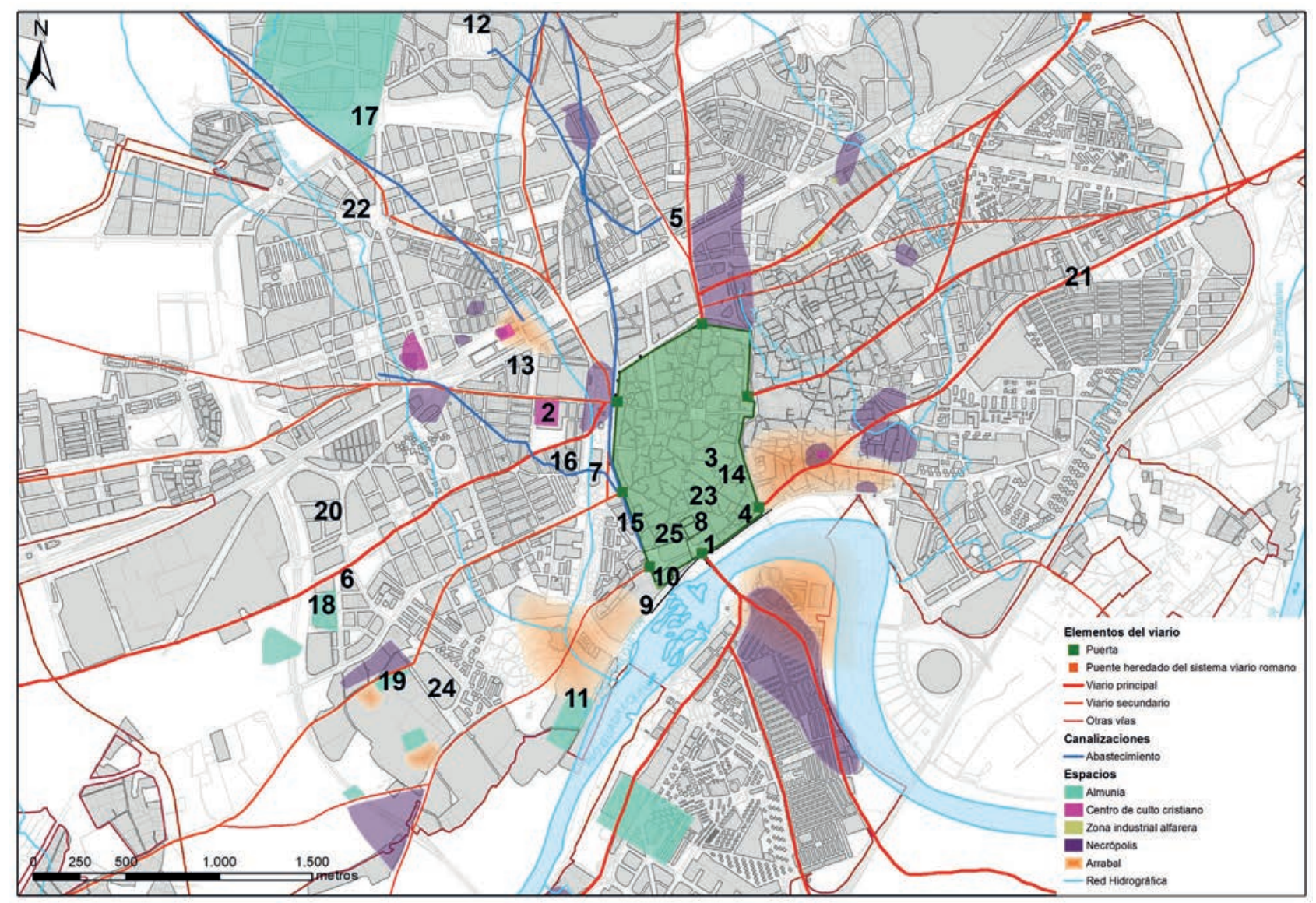

Figura 1. Plano de localización de los restos mencionados relativos a la ciudad de Córdoba: 1.- Puerta del Puente (solar del actual Centro de Recepción de Visitantes); 2.- Posible espacio de culto de carácter martirial emplazado en la arena del anfiteatro romano; 3.- Graderío del teatro romano, Museo Arqueológico de Córdoba (plaza Jerónimo Páez); 4.- Ronda de Isasa, no 4; 5.- Avda. Llanos del Pretorio, Córdoba (en la nueva sede de EMACSA); 6.- Manzana 14 Plan Parcial 0-7; 7.- Excavación del Parque Infantil de Tráfico, en los Jardines de la Victoria; 8.- Mida'a o pabellón de abluciones oriental de la Mezquita aljama emiral; 9.- "Al-rasif", malecón emiral en la muralla de la Huerta del Alcázar; 10.- "Patio de Mujeres" del Alcázar de los Reyes Cristianos de Córdoba; 11.- Excavación arqueológica en el Zoológico Municipal de Córdoba (¿la almunia Balat Mughit?); 12.- Hospital La Arruzafa, (esquina entre la C/ Poeta Valdelomar Pineda y la C/ Marino Alcalá Galiano); 13.- C/ Albéniz, no 2; 14.- C/ Antonio del Castillo, no 3; 15.- Parking la Mezquita de Córdoba, C/ Cairuán, no 1; 16.- C/ Secretario Carretero, esquina con C/ Antonio Maura; 17.- Tablero Bajo, en las inmediaciones de la antigua Huerta de la Arruzafa; 18.- Parcela 2 del PPO7; $19 .-$ Almunia excavada en las naves municipales de la zona de Fontanar de Cábanos (junto a C/ Dr. Gonzalo Miño Fugarola); 20.- Parcela 16A del Plan Parcial PPO7 (C/ Escritora María Goiry); 21.- Parcela 1.1. F3 de la Avda. de Libia; 22.- Ctra. Santa María de Trassierra y la Avda. Cañito Bazán de Córdoba; 23.- Mezquita conservada en el antiguo convento de Santa Clara; 24.- Mezquita de Fontanar; 25.- Centro de Arte Contemporáneo de la Fundación Botí (C/ Calle Manríquez, 5, junto a la Plaza Judá-Lévi). (Plano de base (c) Convenio GMU-UCO).

hasta constituir procedimientos constructivos bastante estandarizados que se combinan con la sillería en los nuevos modelos edilicios propios la arquitectura oficial.

Finalmente, un estudio como el que ahora presentamos cuenta con el hándicap añadido del estado de conservación de la mayoría de las estructuras. Salvo casos excepcionales, el nivel de arrasamiento sólo permite apreciar las hiladas inferiores de los muros, lo que impide precisar el tipo de técnica constructiva del alzado completo del edificio. Esta limitación se traduce en la indefinición a la hora de catalogar los tipos de aparejos mixtos documentados en las intervenciones arqueológicas en la ciudad, por lo general identificados bajo el término genérico de "opus africanum". Sin embargo, es posible distinguir otros tipos en los que alternan la sillería y los cajones de mampuestos, como el aparejo en damero o ajedrezado.

Por lo que respecta a la terminología que empleamos en relación con la técnica de cadenas verticales de bloques de sillar, hemos mantenido la denominación clásica de "opus africanum", pese a las lógicas reticencias por el uso de esta terminología en construcciones medievales. Además, para que una estructura se ajuste

\footnotetext{
Esta técnica mixta se conoce también como "de osamenta o relleno", "opera a telaio" o "aparejo de marco" (Adam 1996: 131).
} 
plenamente a esta técnica, las cadenas verticales de sillares que soportan la estructura deben alternar los bloques verticales y horizontales que sobresalen de aquellas, lo que permite trabar mejor los rellenos intermedios de mampuestos (Adam 1996: 130-131). No siempre es posible constatar todas las características que definen el tipo, pues se suelen conservar únicamente las primeras hiladas de los sillares verticales. Pese a ello, nos hemos decantado por mantener la convención del uso del término clásico por su valor evocador y su reconocimiento generalizado. Cuando la estructura no se ajusta clara y estrictamente a las características básicas del tipo constructivo, pero su apariencia es un remedo muy similar, hemos matizado el término con la denominación de pseudo opus africanum.

En cualquier caso, la construcción de una cronotipología requiere de una muestra más amplia de la que ahora presentamos en la que se establezcan los criterios discriminantes para establecer y aquilatar las variantes. Conscientes de ello, nuestra aproximación pretende tan sólo sentar las bases para estudios posteriores.

\section{APAREJOS MIXTOS TARDOANTIGUOS EN CÓRDOBA}

El repertorio de aparejos mixtos que recopilamos en este trabajo para época omeya tiene claros precedentes durante la etapa tardoantigua en la propia ciudad de Córdoba, apenas estudiados (León 2006), y en otras áreas peninsulares, donde sí han sido objeto de recientes revisiones (Beltrán y Macías 2016; Sarabia 2013).

En todos los casos responden a algunas de las características propias de la arquitectura de la Antigüedad Tardía; esto es, heterogeneidad en los aparejos como consecuencia del uso recurrente de spolia, en los que la alternancia de los encadenados verticales de sillería no mantiene ni la disposición ni la regularidad de las estructuras de época romana (Beltrán y Macías 2016: 25). La mayoría de las estructuras pertenecen a edificios de cierta entidad monumental, lo que permite asociarlos más o menos claramente con funciones públicas $\mathrm{y}$, en particular, de carácter religioso.

Por la entidad del conjunto arquitectónico, destacan los paramentos excavados junto a la Puerta del Puente (en el solar del actual Centro de Recepción de Visitantes), documentados durante la intervención preventiva (Casal y Salinas 2009) y el posterior seguimiento de la obra, pertenecientes a un gran edificio situado junto a la muralla meridional de la ciudad. La integración de las estructuras excavadas en distintas intervenciones (Plaza del Triunfo, 2 y Ronda de Isasa) definen un gran edificio organizado en torno a un espacio abierto central al que abren varias estancias de considerables proporciones, pavimentadas con suelos de opus signinum. A los efectos que ahora nos ocupan, interesan los paramentos de los potentes muros meridionales, dispuestos en paralelo a la muralla, "realizados con mampuestos alternando con sillares de calcarenita de grandes proporciones y algunas piezas arquitectónicas reutilizadas", con una anchura de entre 1,20-1,50 m y una potencia media conservada de $1 \mathrm{~m}$ (Casal y Salinas 2009: 716). En estas estructuras se combinan varias técnicas mixtas: en el muro de fachada meridional alternan los encadenados verticales de sillería reutilizada, dispuestos a intervalos regulares, con tramos de mampostería irregular (identificado como pseudo opus africanum) (Fig. 2a); en otros tramos de muros internos se alternan de forma irregular mampuestos trabados con mortero terrizo con bloques de sillería ${ }^{4}$ (Fig. 2b); y en las estructuras más orientales los muros están realizados íntegramente en sillería reutilizada. La potencia y las características constructivas de estas estructuras han llevado a vincular este edificio "con la residencia del poder civil de la ciudad que se presupone estaría en un área cercana al centro de culto y a la muralla meridional" (Casal y Salinas 2009: 716). Esta interpretación ha sido recientemente matizada con una nueva propuesta que integra este edificio en el complejo episcopal de la ciudad (León y Murillo 2009: 405; Murillo et alii 2009-2010: 521-522), formando parte de las estructuras de función administrativa y económica, vinculadas con las actividades propias del área portuaria fluvial.

La cronología de este conjunto arquitectónico se sitúa, según las más rigurosas revisiones (Ruiz Bueno 2016: 400-401) $)^{5}$, entre finales del siglo VI y siglo VII, sobre la base del estudio de materiales asociados a la secuencia estratigráfica. En concreto, en uno de los paquetes sedimentarios de relleno previos a la construcción del edificio se ha recuperado "un borde de cuenco que

\footnotetext{
Similar a los paramentos de la última fase del gran edificio portuario documentado en la l'Illa Sud en la ciudad de Tarragona, fechados en el siglo VII (Díaz y Roig 2016: 87-89) y en la estructura identificada como una fortificación visigoda excavada en la calle Tapiería de Valencia (Beltrán y Macías 2016: 26).

5 Ruiz Bueno, M. D. 2016: Topografía, imagen y evolución urbanística de la Córdoba clásica a la tardoantigua (ss. II-VII d. C.). Tesis doctoral inédita. Córdoba. [En línea] http://helvia.uco.es/xmlui/handle/10396/14142?show=full
} 
pudiera corresponder al tipo Hayes 93 B / Fulford 50", cuya producción se inicia después del $500 \mathrm{~d}$. C. y tiene su "etapa de apogeo entre el 525 y 575 d. C." (Vargas et alii 2007: 166).

En el espacio suburbano se documenta otro proyecto edilicio de gran envergadura y complejidad arquitectónica durante el periodo tardoantiguo, que se ha vinculado con un posible espacio de culto de carácter martirial emplazado en la arena del anfiteatro romano (Vaquerizo y Murillo 2010) ${ }^{6}$. En las primeras campañas de excavación (iniciadas en 2003) se documentaron tres estructuras semicirculares (de c. 8,3 m de diámetro exterior) adosadas al muro del pódium del anfiteatro, cuyos sillares son retallados para encajar y ensamblar correctamente las nuevas construcciones. Estas estructuras están realizadas con una técnica edilicia mixta de gran solidez y calidad, con muros de circa $1 \mathrm{~m}$ de grosor y una altura superior a los $2 \mathrm{~m}$, que podríamos catalogar con seguridad como opus africanum (Fig. 2c), con pilares verticales de sillería reutilizada en los que alternan bloques verticales y horizontales que sobresalen lateralmente respecto de los anteriores, dispuestos radialmente y con un relleno de opus vittatum trabado con un mortero de cal de tonalidad rosácea. Se trata de una técnica edilicia radicalmente distinta a las utilizadas en el edificio de anfiteatro altoimperial, y de una calidad que no encuentra parangón en ninguno de los edificios tardoantiguos documentados en Córdoba. Durante la última campaña de intervención, en 2010, se ha ampliado la superficie excavada ${ }^{7}$, lo que ha permitido documentar entre las estructuras semicirculares una serie de, al menos, tres corredores de trazado rectilíneo, con una orientación divergente con respecto al graderío del anfiteatro, a los que se ingresa mediante la apertura de un vano en el cierre del pódium. Los muros que delimitan estos corredores están formados por gruesos cimientos de $1,20 \mathrm{~m}$ de anchura y unos alzados realizados con la misma técnica edilicia; esto es, una fábrica mixta consistente en tramos de mampostería que alternan con gruesos refuerzos en las esquinas con sillería reutilizada

\footnotetext{
${ }^{6}$ La interpretación como centro martirial ha sido cuestionada por R. Hidalgo, quien vincula las estructuras semicirculares con una refectio del anfiteatro (Hidalgo 2012: 261). Dicha crítica no ha tenido en cuenta las incuestionables evidencias estratigráficas que desvinculan las estructuras circulares adosadas al podio con la fase constructiva del edificio de espectáculos altoimperial. Esta alternativa queda totalmente descartada con la presencia de estructuras en el espacio ocupado por la arena y que fueron omitidas en dicho trabajo.

Rodríguez Sánchez, M. ${ }^{\text {C C } ~ e t ~ a l i i . ~ 2016: ~ I n f o r m e-M e m o r i a ~ F i n a l ~ d e ~ l a ~ A . ~}$ A. Pre. en el Anfiteatro de Córdoba. Informe administrativo depositado en la Delegación de Cultura de Córdoba (inédito), Córdoba.
}

del propio anfiteatro y trabados con un singular mortero de cal rosáceo, que distingue las estructuras pertenecientes a esta fase tardoantigua. La cota de pavimento de dichos corredores coincidiría, según sus excavadores, con el nivel original de la arena del anfiteatro. Muchas de estas estructuras fueron sometidas a un intenso saqueo en época omeya (siglos IX y, en especial, siglo X), con la apertura de fosas para la extracción de material constructivo y la excavación de amplios pozos para su uso como basureros. Las más recientes actuaciones en el yacimiento han aportado datos muy valiosos que han permitido aquilatar bastante el momento de construcción de este nuevo proyecto edilicio. Los repertorios cerámicos recuperados de los rellenos asociados a los procesos constructivos de estas estructuras aportan algunas piezas africanas de cocina que marcan una datación post quem comprendida entre el año 325 y el 400-420 d. C. ${ }^{8}$ La información aportada por estas estos materiales apunta a mediados del siglo IV como el momento más probable para la erección de este nuevo complejo arquitectónico de gran complejidad y difícil interpretación. Pese a la dificultad, la entidad de las estructuras y, en especial, la abundante información recuperada en el entorno inmediato, abundan en la idea de transformación del anfiteatro romano en un complejo arquitectónico monumental; más concretamente, un probable centro de culto cristiano de carácter martirial. No obstante, es necesario demandar prudencia en las interpretaciones en tanto nuevas campañas de excavación no proporcionen un conocimiento más profundo, tanto de las características arquitectónicas de estas edificaciones, como de su horizonte cronológico y posibles usos.

En el interior de la ciudad amurallada se han documentado más estructuras realizadas con aparejos mixtos. En el espacio ocupado por el graderío del teatro romano, una vez desmontado y expoliado durante el siglo $\mathrm{V} \mathrm{d}$. C., se levantan algunas construcciones - un potente muro de contención para el aterrazamiento de la zona y muros de una casa - que muestran un incipiente proceso de urbanización de la zona, datado en la primera mitad del siglo VII. La descripción hecha por sus excavadores de la técnica constructiva, tanto de la cimentación como de los alzados de estos muros, con sillares reutilizados dispuestos verticalmente que enmarcan "casetones de ripios" en los que alternan ladrillos y cantos "recuerda [...], salvando las necesarias distancias, al opus africanum clásico" (Monterroso y Cepillo 2002: 163) (Fig. 2d).

8 Rodríguez et alii 2016. 


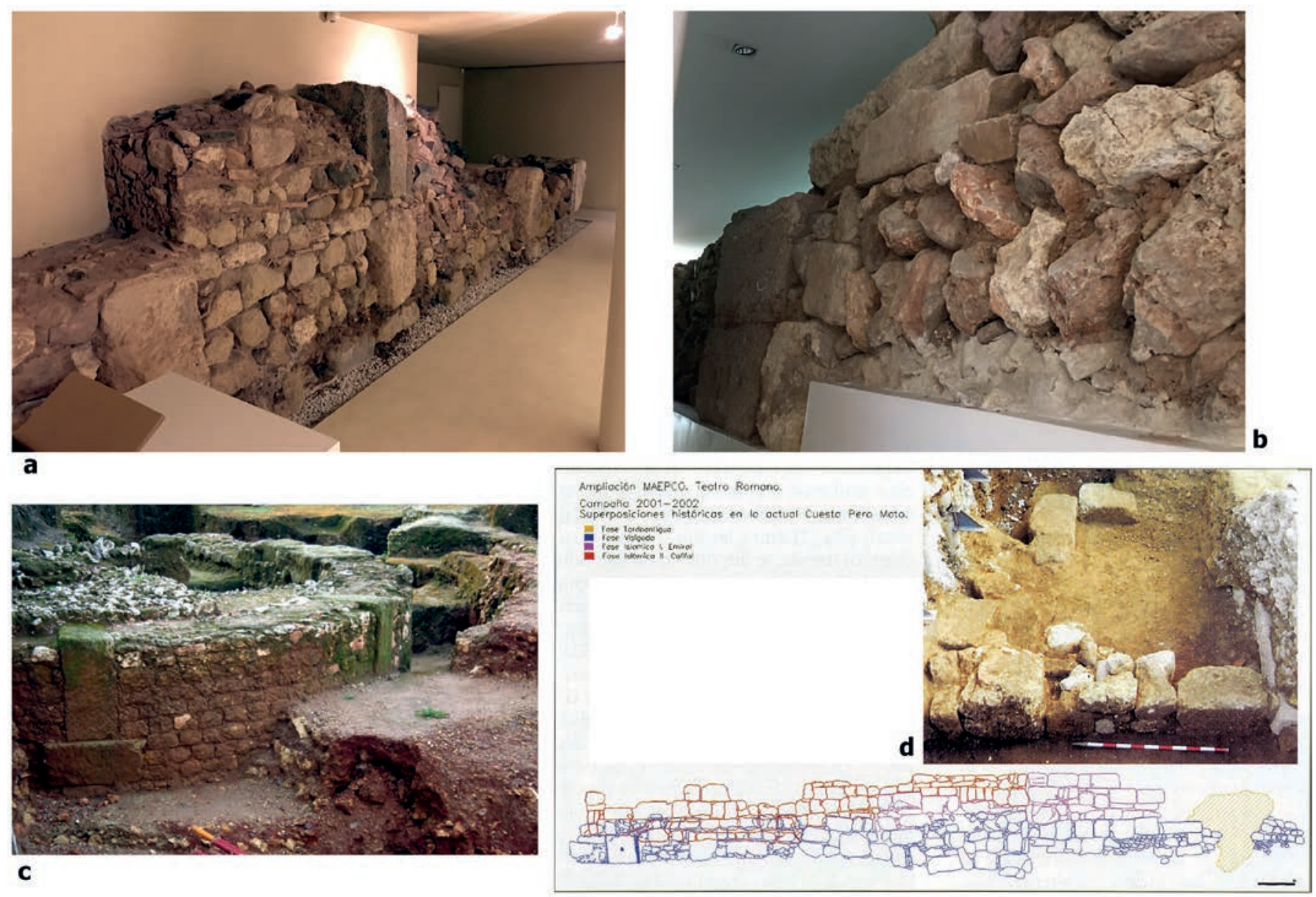

Figura 2. Paramentos de época tardoantigua en Córdoba en los que se emplea el opus africanum: a y b.- Edificio excavado junto a la Puerta del Puente (en el solar del actual Centro de Recepción de Visitantes; c.- Detalle de una de las tres estructuras semicirculares adosadas al muro del pódium del anfiteatro (Rodríguez et alii 2016; (c) GMU-UCO); d.- Estructuras tardoantiguas documentadas en la excavación del antiguo teatro romano de la ciudad (Monterroso y Cepillo 2002).

Igualmente, en la esquina suroriental del recinto amurallado de la ciudad tardoantigua se identifican otras estructuras con técnicas mixtas, excavadas en la Ronda de Isasa, $n^{0} 4$, datadas en el siglo VI-VII (Ruiz Bueno 2016: 433-435). En este caso, la escasez de la muestra, con muros inconexos que no definen un edificio completo, impide apreciar la continuidad de la técnica. Destacamos, en este caso, el paramento levantado con sillares de calcarenita reutilizados que alternan con rellenos cajeados de mampostería, a la manera de un remedo del aparejo en damero (Fig. 3a).

Además de los restos de la arena del anfiteatro, en los suburbios de Córdoba también se documentan construcciones de distinta entidad que muestran aparejos con técnicas mixtas. En algunos casos se trata de estructuras aisladas, que no se pueden vincular con ningún edificio concreto. Este es el caso del muro documentado en la intervención arqueológica en la Avda. Llanos del Pretorio, Córdoba (en la nueva sede de EMACSA) y adscrito a una "fase bajoimperial-tardoantigua". El muro divide por la mitad la cámara de cocción de un horno de cerámica previo y está realizado con la técnica de pseudo opus africanum, "con una cimentación de una hilada de mampuestos de tamaño medio sobre la que descansan otras tres hiladas más separadas en tramos de 1,30-1,50 $\mathrm{m}$ por sillares colocados en horizontal y vertical con unas dimensiones medias de 0,70 x 0,50 m" (Cánovas y Sánchez 2009) (Fig. 3b).

Un último ejemplo en el que se documenta una alternancia regular de pilares de sillería y rellenos intermedios de mampostería trabada con cal, identificada como "una fábrica de opus africanum", fue excavado en la intervención Arqueológica Preventiva en la Manzana 14 Plan Parcial O- $7^{9}$ (Clapés 2013: 98), bajo el patio de una casa

\footnotetext{
Clapés Salmoral, R. 2010: Informe Preliminar A. A. Pre. Manzana 14 Plan Parcial O-7, Córdoba. Informe administrativo depositado en la Delegación de Cultura de Córdoba (inédito), Córdoba.
} 
de época califal. Dicha estructura define el muro oriental de cierre de un posible recinto funerario, en cuyo interior se han excavado dos inhumaciones en fosa simple con cubierta de tégulas. Las características constructivas de este muro le confieren algunas particularidades, como la forma ligeramente rectangular de los sillares de calcarenita, dispuestos sobre la tabla en lugar de su disposición vertical habitual o a sardinel (Fig. 3c). En esta ocasión, la estructura documentada no forma parte del alzado del edificio, sino que corresponde a la cimentación, de las que se conservan dos hiladas, por lo que más que denominarlo como un aparejo de opus africanum propiamente dicho, deberíamos considerarlo como una solución habitual para sustentar elementos portantes verticales, como columnas, pilares o similares. En tal caso, podría corresponder con el basamento de un espacio porticado en cuyo interior se dispusieron los enterramientos, que se han datado en torno al siglo VI (Clapés 2013: 98, nota 6). La entidad de las estructuras y su función funeraria parecen vincular este edificio con un centro de posible carácter religioso, aunque no existen elementos de clara adscripción litúrgica que permitan identificarlo con alguno de los edificios martiriales que las fuentes sitúan en las áreas suburbanas. El mejor paralelo para esta técnica constructiva se encuentra en el gran edificio tardoantiguo excavado en el Patio de Banderas del Alcázar de Sevilla. Dicha construcción, interpretada hipotéticamente como un posible monasterio datado en el siglo $\mathrm{V}$, se organiza en torno a un patio central porticado, del que se ha documentado la cimentación, consistente en un aparejo mixto de mampostería caliza, de tamaño mediano y disposición irregular, y "fragmentos de ladrillos que a intervalos regulares de 2 metros presenta la incorporación de un sillar alcorizo de $0.72 \times 0.52 \times 0.25$ sobre el que se apoyan basas de mármol reutilizadas marcando la ubicación de las columnas" (Tabales et alii 2016: 163). Se conserva una de las basas áticas reutilizada sobre las que se colocaban las columnas del espacio porticado central.

Otro recinto de carácter funerario, posiblemente vinculado a un centro religioso, datado entre los siglos V y VI d. C., es el documentado en la excavación del Parque Infantil de Tráfico, en los Jardines de la Victoria. En este caso, la técnica mixta no parece corresponder propiamente a un opus africanum, como en alguna ocasión se ha propuesto (León 2006), sino que se trata de un muro realizado con mampostería y sillería, con una alternancia de mampuestos, ladrillos y tegulae trabados con barro, reforzado en el extremo oeste con grandes sillares encadenados de calcarenita reutilizados de la domus sobre la que se apoya (Castro, Pizarro y Sánchez 2006: 105-106) (Fig. 3d). Las características técnicas de esta estructura han hecho plantear su vinculación con un edificio cubierto de cierta envergadura, acaso un edificio de culto (Castro, Pizarro y Sánchez 2006: 113). Esta técnica de mampuestos con encadenados en las esquinas es muy similar a la empleada en los paramentos del palacio del obispo del complejo episcopal de Barcelona (Beltrán y Macías 2016: 34, fig. 20.3).

En la arquitectura tardoantigua peninsular encontramos varios ejemplos de construcciones cuyos alzados están realizados con esta técnica mixta de opus africanum, por lo general en estructuras vinculadas con edificios públicos, en especial, de carácter religioso.

Una disposición tan cuidada de los bloques de sillería del encadenado vertical se aprecia en Mértola (Portugal), en el edificio documentado bajo la quibla de la mezquita almohade (Gómez 2011: 102). Los muros realizados con esta técnica alternan los bloques de sillería de granito y una mampostería de pizarra local trabada con mortero de cal (Fig. 3e). Las estructuras documentadas definen la esquina de un edificio interpretado como el ábside de una iglesia tardoantigua, para el que se han propuesto dos dataciones distintas: "entre os finais do seculo IV inicios do V" (Lopes 2014: 151), o "probablemente del siglo VI d. C." (Gómez 2011: 102).

Una muestra del empleo de la técnica del opus africanum en paramentos que alternan los encadenados verticales de sillería y relleno intermedio de "pseudo vittatum" trabado con mortero de cal se encuentra en el área arqueológica de San Pere, en Tarragona, un conjunto datado entre los siglos V y VI d. C., que conserva un excepcional alzado de varios metros (Beltrán y Macías 2016: 29 y 34, figs. 15 y 20.1-2). La proximidad con otras estructuras monumentales, como una columnata de piezas reutilizadas, se ha puesto en relación con la existencia de una posible iglesia en las inmediaciones (Macías 2015: 49), integrada en un proyecto arquitectónico hipotéticamente promovido por una iniciativa monástica (Macías 2014: 461-463).

El repertorio de estructuras en la arquitectura tardoantigua hispánica en las que se emplean estas técnicas mixtas, en particular el opus africanum y la alternancia de mampostería con sillares de acarreo, se ha visto enriquecido con recientes estudios regionales. En Barcelona se ha documentado esta técnica en varios de los edificios vinculados con el complejo episcopal, fechados en el mismo siglo VI, y en el área del foro de la colonia, en este caso, del siglo VII (Beltrán 2016: 64-65). 

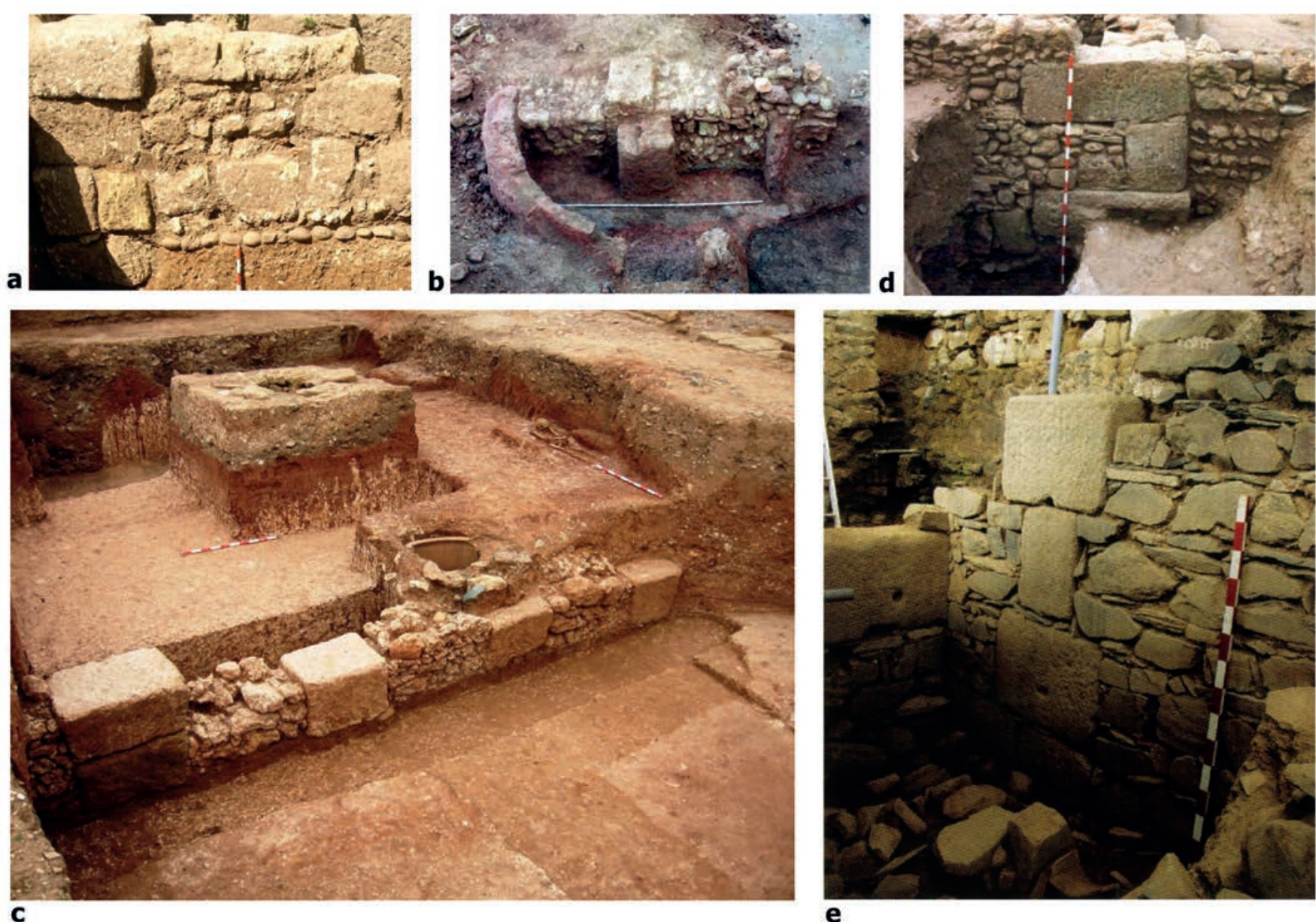

Figura 3. Aparejos mixtos tardoantiguos en Córdoba: a.- Remedo del aparejo en damero en Ronda de Isasa, no 4 (Ruiz Bueno 2016: 433-435); b.- Avda. Llanos del Pretorio, Córdoba (nueva sede de EMACSA; (C) GMU-UCO) (Cánovas y Sánchez 2009); c.- Manzana 14 Plan Parcial O-7 (Clapés 2010); d.- Parque Infantil de Tráfico (Castro, Pizarro y Sánchez 2006); e.- Mértola (Portugal) (Gómez 2011: 102).

Además de los edificios de carácter religioso, también se documenta esta técnica en la arquitectura civil, como hemos visto en Córdoba. En Valencia se conserva un tramo de la muralla de la C/ Tapiería levantado con este aparejo, datado en el siglo VI (Sarabia 2013: 150). El baluarte defensivo del Tolmo de Minateda cuenta con un sólido aparejo externo con sillares dispuestos a tizón, calificado como opus africanum. En realidad, se trata de un forro de la muralla previa en el que se emplean estos tirantes de sillería con material de acarreo (Sarabia 2013: 159; Vizcaíno 2007: 416). En el denominado castellum de San Juliá de Ramís (Girona) se documenta algún muro con esta técnica (Beltrán y Macías 2016: 26-27). En Tarragona, algunos de los grandes edificios de carácter productivo emplazados en el área portuaria, fechados en el siglo VII, se levantan con estos mismos encadenados verticales de sillería y rellenos de mampostería (Díaz y Roig 2016: 88-90). En Mérida también se documentan algunos edificios con paramentos que muestran una técnica similar, como el excavado en "el corralón de Blanes", fechado en el siglo V o en el localizado en la calle John Lennon, $\mathrm{n}^{\circ} 28$, adscrito a los siglos V-VI (Beltrán y Macías 2016: 25).

El amplio muestrario de edificios en los que se emplea este tipo de aparejo en época tardoantigua parece estar indicando un ambiente técnico común extendido por muy diferentes áreas de la península ibérica, en especial, en aquellas que tienen un cierto carácter cosmopolita por su condición portuaria o comercial, abiertas a las influencias de otras zonas del Mediterráneo tardoantiguo (Sarabia 2013: 159) desde el que pudieron transferirse procedimientos técnicos propios de la arquitectura monumental y que, como veremos, tendrán su continuidad en época islámica. 


\section{APAREJOS MIXTOS DE ÉPOCA EMIRAL EN CÓRDOBA}

El dinamismo arquitectónico de la ciudad de Córdoba durante la etapa tardoantigua se verá significativamente revitalizado tras la conquista islámica, a partir de su elección como capital del territorio andalusí y, en especial, tras la emancipación del gobierno autónomo omeya de al-Ándalus, como emirato independiente.

La estandarización de un procedimiento constructivo en sillería aparejada de forma regular se inicia con la construcción de la mezquita aljama de Abd al-Rahman I en 785-786. Desde ese instante, la mayoría de los nuevos proyectos arquitectónicos y urbanísticos oficiales desarrollados en la capital y auspiciados por el poder emplearán el aparejo de sillería a soga y tizón hasta hacer de esta técnica un signo distintivo de las construcciones omeyas andalusíes, en especial, en la capital del flamante Estado (cfr. Gurriarán 2004 y 2008; León 2008).

No obstante, desde el primer momento del que tenemos información documental, se mantienen procedimientos constructivos de raigambre tardoantigua, ya sea en el ámbito doméstico como en obras de infraestructura públicas. Así, por ejemplo, en algunas casas excavadas en Sequnda (Casal 2008: 122) y en el Zoológico de Córdoba (Ruiz Lara et alii 2008: 173) se documenta el empleo de tegulae como sistema de cubierta; por otro lado, se mantiene el uso generalizado de material de acarreo, reaprovechando la piedra de estructuras preexistentes. Este es el caso de la conocida referencia a las primeras reparaciones del puente mayor entre los años 719-720. Esta noticia, recogida en los Ajbar Machmua (Lafuente 1867: 35 de la traducción), complementada con la información aportada por Ibn al-Qutiyya, ha sido reproducida en la mayoría de los trabajos relacionados con la técnica constructiva andalusí en piedra (Azuar 2005: 150; Gurriarán 2004: 300 y 2014: 264; León 2006: 424 y 2008: 61; Malpica 1998: 314). Es lógico pensar que en éstas como en otras construcciones se mantiene el peso del substrato material, técnico y cultural preislámico, habida cuenta de que la mayor parte de la mano de obra que acomete y ejecuta estos proyectos era la población local cristiana ${ }^{10}$.

\footnotetext{
10 Su protagonismo debió de ser mucho menor en el diseño de las obras emblemáticas omeyas, como la mezquita, alcázar o Rusafa, para las que es plausible pensar en una mayor influencia foránea.
}

Por otra parte, el volumen de material demandado por las nuevas construcciones a partir de la generalización de la sillería a principios del siglo IX debió de hacer muy difícil el abastecimiento de piedra de cantera para todas las nuevas construcciones. Es muy probable que la demanda no pudiera cubrirse totalmente hasta el establecimiento de procedimientos muy bien organizados de explotación de las canteras a gran escala ya en época califal, con los que afrontar las necesidades de material de los numerosos proyectos arquitectónicos y urbanísticos oficiales, como la ampliación de la mezquita, la reparación del puente y del alcázar omeya y, en especial, la erección de la ciudad califal de Madinat al-Zahra ( $c f r$. Gurriarán 2008; León 2008; Vallejo 2010; Vallejo y Fernández 2010).

De ahí que, pese a disponer de recursos materiales y competencias técnicas para abordar obras de gran entidad, constatadas ya en la primera mezquita, se intente optimizar los medios disponibles con la utilización de aparejos y técnicas mixtas en las que se alternan los sillares con la mampostería. Y estos aparejos mixtos se combinan, a su vez, con paramentos en los que se emplea únicamente la sillería. Así, por ejemplo, en época de Hisham I, a finales del siglo VIII, se está empleando la sillería de cantera aparejada a soga y tizón para levantar el primer alminar de la mezquita aljama, del que se documentaron las primeras cuatro hiladas de su alzado (Hernández 1975: 131), mientras que la mida'a o pabellón de abluciones oriental se construye con mampostería que alterna sin un ritmo regular con piezas de sillería reutilizadas ( $c f r$. Marfil 1999) (Fig. 4). Algo similar sucederá en época califal en la conocida mezquita de Fontanar en la que se emplea un aparejo en damero para los muros que delimitan el oratorio, mientras que en los accesos y en el alminar se utilizan bloques de sillería aparejados regularmente (Luna y Zamorano 1999). Esta dualidad de técnicas en edificios de carácter oficial podría deberse a la selección y reserva de los materiales más nobles y regulares para las puertas y los alminares, pues en ellos se plasma, en cierto modo, el símbolo de la presencia y dominio islámico sobre la ciudad y su territorio ( $c f r$. González 2016: 424). Sea como fuere, no debemos olvidar que en todos los casos los paramentos estuvieron revestidos con una capa de mortero de cal que enmascaraba la fábrica de los muros. 


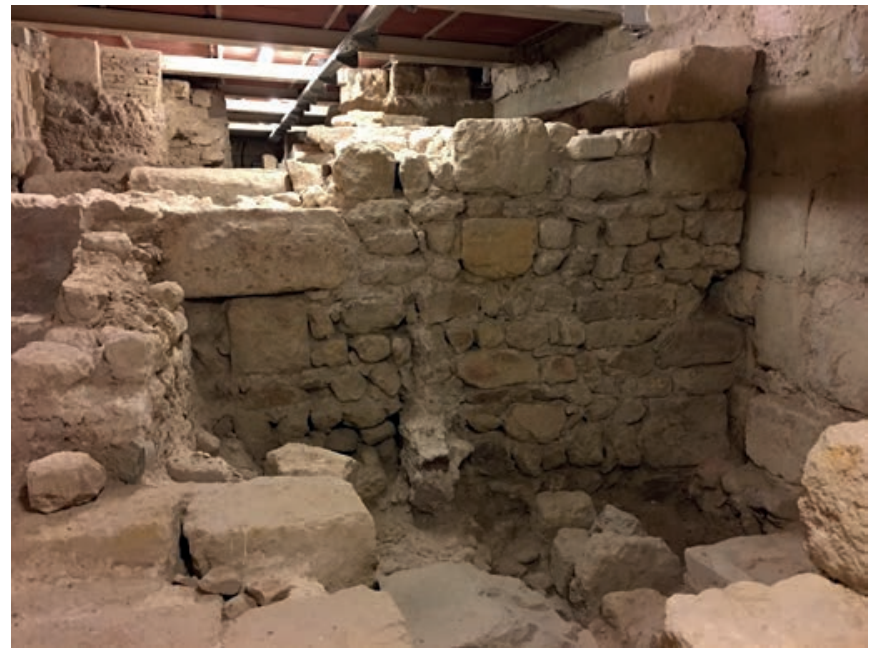

Figura 4. Fachada septentrional del pabellón de abluciones de Hisham I en el costado oriental de la mezquita aljama de Córdoba (fotografía del autor).

Hemos organizado en tres grandes tipos básicos el amplio repertorio de testimonios documentados hasta el momento, en los que la sillería alterna con mampostería para componer los aparejos mixtos:

1. Paramentos externos de sillería e internos de mampostería o con encadenados verticales, a modo de opus africanum.

2. Aparejos de opus africanum o de encadenados verticales de sillería.

3. Aparejo en damero.

\section{Paramentos externos de sillería e internos de mampostería o con encadenados verticales, a modo de opus africanum}

El primer tipo mencionado se corresponde con construcciones oficiales de gran entidad, directamente vinculadas con el propio conjunto palatino y su entorno inmediato, en las que ha sido posible aquilatar con precisión su cronología en época del emir Abd al-Rahman II.

La primera de estas estructuras es la documentada en varios sondeos de la Intervención Arqueológica en la denominada muralla de la Huerta del Alcázar, con varios tramos excavados a lo largo de más de $120 \mathrm{~m}$ de longitud, una altura total conservada de casi $5 \mathrm{~m}$ y más de tres metros de anchura (Murillo et alii 2009-2010: 186-194).
Se trata del malecón fluvial levantado mediante un doble sistema constructivo: la fachada exterior (meridional) está formada por grandes sillares de calcarenita, de la que se han podido documentar solo tres hiladas dispuestas a tizón (Fig. 5a), trabadas con mortero de cal que, además de mostrar el aparejo noble al exterior, servía como muro de contención de los encofrados y mampuestos del paramento interno; por su parte, el muro interior (septentrional) emplea un aparejo mixto identificado como opus africanum en el que se alternan pilares o encadenados verticales de sillería de gran módulo que van trabando una fábrica de mampostería con mortero de cal.

Además de la combinación de estos dos procedimientos, que definen el tipo arquitectónico, en esta ocasión interesa particularmente la técnica empleada en el paramento interior. Los sólidos pilares de sillería presentan una disposición escalonada, a la manera de "zarpa", con mayor anchura en la base que en las hiladas superiores, mostrando una forma de $\mathrm{T}$ invertida (Fig. 5b). Los sillares están trabados con abundante mortero de cal, al igual que los rellenos de mampostería bien aparejados que cierran los espacios entre los encadenados verticales. A diferencia de lo que sucede con el paramento meridional, que define claramente una fachada exterior, la irregularidad de la alineación de la potente estructura interior evidencia que no fue nunca vista, sino que su función era meramente estructural, destinada a contener unos potentes rellenos antrópicos de gravas y arenas compactados que cubrían las estructuras descritas y aterrazaban el terreno (Fig. 5b), sobre los cuales se apoyaba el rasif o pavimento empedrado propiamente dicho, del que se ha documentado una reparación califal (Murillo et alii 2009-2010: 194).

Los materiales recuperados del interior de estos rellenos permiten datar la estructura durante la primera mitad del siglo IX (Murillo, Casal y Castro 2004: 265; Murillo et alii 2009-2010: 189). Pero, además de estos materiales, contamos con unas referencias textuales muy explícitas que permiten aquilatar de forma excepcional el momento y la autoría de su construcción, datado en 827-828 d. C. (212 H.). Gracias a la información aportada por el Muqtabis II-1 (Ibn Hayyan 2001: 172), es posible identificar esta estructura con el malecón junto al río, sobre el que se apoyaba el camino empedrado o "al-rasif" que discurría al sur del alcázar, y que fue mandado construir por el emir 'Abd al-Rahman II: 

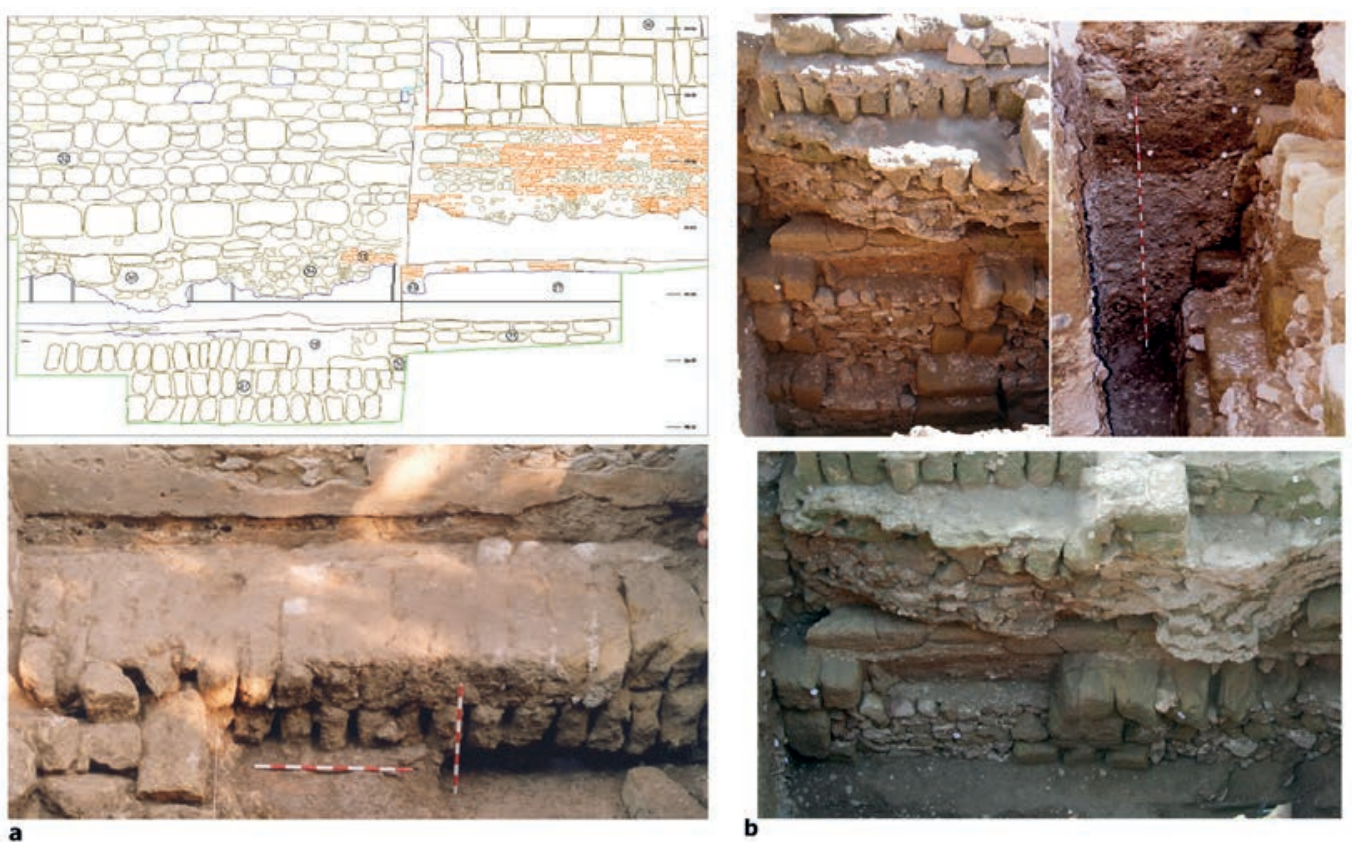

Figura 5. Malecón emiral de Córdoba, excavado en la denominada Muralla de la Huerta del Alcázar (Murillo et alii 2009-2010): a.- Alzado del paramento externo de sillería; b.- Detalles del paramento interno con la técnica de encadenados verticales de sillería.

Él fue quien hizo la azotea que dominaba la principal puerta del Alcázar califal, la primera meridional, llamada Puerta de la Azuda (Bab assudah), poniéndose encima como una corona, con lo que se completó su extraordinaria majestuosidad; él fue quien construyó el malecón en la orilla del Guadalquivir ocupada por la muralla, el Alcázar y la ciudad, en prevención de los embates de las inundaciones, colocando este malecón contra las crecidas, mediante una perfecta disposición que trababa las piedras asentadas con mortero, y allanando encima / el camino, que quedó expedito a los viandantes y convertido en defensa contra las avenidas del río, obra de cuya supervisión se encargó su hombre de confianza Ahmad Al'Ubti en el año $212 \mathrm{H}$.

En el libro de Ibn Mu'awiyyah [...] dice que [...] Él fue también quien construyó el malecón a orillas del río en la parte sudoeste del Alcázar, prolongándolo desde el ángulo oriental de la ciudad hasta el extremo del ángulo occidental del alcázar, añadiendo a este ángulo una prolongación que lo une con la margen del gran zoco de Córdoba, y dejando el cerro llamado de Abd Abdah en la Puerta del Arsenal [...] septentrional entre las del Alcázar, dentro del cual también hizo grandes construcciones y maravillosas obras que se le atribuyen (Ibn Hayyan 2001: Muqtabis II-1, 172).

Precisamente, en relación con la noticia anterior, una variante de esta solución arquitectónica mixta se puede apreciar en el interior del denominado "Patio de Mujeres" del Alcázar de los Reyes Cristianos de Córdoba ${ }^{11}$. En la excavación de dicho patio oriental se ha documentado una potente estructura que emplea una singular técnica mixta, consistente en un paramento exterior de sillería, dotado de contrafuertes, y un muro interior de mampostería, reforzado por la existencia de una hilera de columnas reutilizadas, pertenecientes a un edificio preexistente de época tardoantigua, que pudo funcionar a modo de encadenado vertical en el núcleo del muro. La peculiaridad de esta técnica se debe a la reutilización y adaptación de estructuras previas pertenecientes a un recinto tardoantiguo, que hemos venido en denominar "castellum" (León y Murillo 2009). En el interior de dicho edificio tardoantiguo se dispusieron varias hiladas de columnas reutilizadas, definiendo un espacio porticado. Los intercolumnios fueron cerrados en un primer momento por un muro de mampostería de anchura similar a las propias columnas ${ }^{12}$. Durante la readaptación de las estructuras en época emiral, las columnas pudieron funcionar como un trasunto de los encadenados verticales del clásico opus africanum.

\footnotetext{
${ }^{11}$ León, A., Murillo, J. F. y León, E. 2008: Informe-Memoria de la Intervención Arqueológica Puntual en el "Patio de Mujeres" del Alcázar de los Reyes Cristianos de Córdoba. Informe administrativo depositado en la Delegación de Cultura de Córdoba (inédito), Córdoba.

12 Un aparejo de opus africanum en el que se reutiliza un fuste de columna se ha documentado en la excavación de la C/ Trapería de Barcelona, datado en el siglo VII (Beltrán 2016: 64-65), aunque no parece un ejemplo parangonable al que aquí mostramos, pues en el caso barcelonés el espacio del intercolumnio es mínimo y la reutilización del fuste es muy parcial.
} 
Los materiales y la técnica edilicia, por un lado, y la entidad de la construcción, por otro, vinculan el edificio con las obras estatales emprendidas en este sector de la ciudad, como parte del proceso de monumentalización arquitectónica del interior del alcázar. Los problemas de presión de los terrenos debieron obligar a reforzar las sucesivas alineaciones de muros previos con una fábrica mucho más sólida, dotada de contrafuertes de sillería y un potente muro de contención, por lo que las soluciones constructivas se deben adaptar a los elementos preexistentes.

Esta estructura omeya define una fachada orientada hacia un patio o espacio abierto dispuesto en su flanco meridional. El paramento exterior estuvo compuesto por varios "pilares" de sillería de calcarenita, y relleno de mampuestos sin que se aprecie mortero de cal en la unión, situados en los intercolumnios, que marcan la línea de fachada de la nueva estructura (Fig. 6a). Al sur de la alineación de columnas y de los pilares de sillería se disponen dos contrafuertes de similares dimensiones $(1,40 / 1,43 \mathrm{~m}$ de anchura x 1/1,02 $\mathrm{m}$ de saliente, respectivamente). En este caso, los sillares sí se encuentran trabados con un grosero y compacto mortero, con numerosos cantos y abundante cal, que le otorgan un "aspecto hormigonado", común a las estructuras de esta fase y que los distingue claramente del utilizado para las obras califales.

Al norte, la cara interior de esta construcción estaba formada por un potente muro de mampostería, que rellena los espacios intermedios entre los diferentes pilares de sillería y las columnas. Se trata de un muro realizado con mampostería de calizas margosas, de colores violetas y azulados, someramente desbastados en su cara externa. Tiene una anchura mínima de $0,65 \mathrm{~m}$ y máxima de $1,85 \mathrm{~m}$, ya que se adapta a los retranqueos marcados por las estructuras de sillería y las columnas (Fig. 6b). Es ligeramente más ancho en su base, donde el aparejo está más cuidado con una buena nivelación de las hiladas trabadas con mortero de cal, visible en las juntas, mientras que en su mitad superior, realizada con el mismo tipo de material constructivo, está dispuesto de un modo algo más irregular, en el que se pierde la nivelación entre las hiladas y los mampuestos se traban con menos mortero. La altura total de esta estructura, a la que consideramos de una única fase constructiva, alcanza los 3,50 m (Fig. 6c). La utilización de la mampostería en este muro frente a la sillería de calcarenita empleada en el paramento externo estaría relacionada con una funcionalidad prioritariamente estructural. Es decir, el muro no estaría destinado a ser visto, sino que serviría como paramento interno, por tanto oculto, o muro de contención de unos potentes rellenos antrópicos de arcilla rojiza, bien compactados, vertidos intencionalmente entre la línea marcada por la antigua muralla tardorromana y las nuevas estructuras emirales situadas al sur, para crear una estructura completamente maciza. Por su parte, el paramento externo de sillería aparejada a soga y tizón sí tendría un evidente valor simbólico, siguiendo los modelos de otras obras oficiales omeyas, relacionado con la arquitectura del poder en la que, sin duda, hay que encuadrar este edificio.

Los materiales recuperados de los rellenos de arcilla remiten a unos contextos muy similares a los documentados en el arrabal emiral del Saqunda, por lo que la cronología propuesta para esta estructura se sitúa en torno al reinado de Abd al-Rahman II (León, León y Murillo 2008: 90-97).
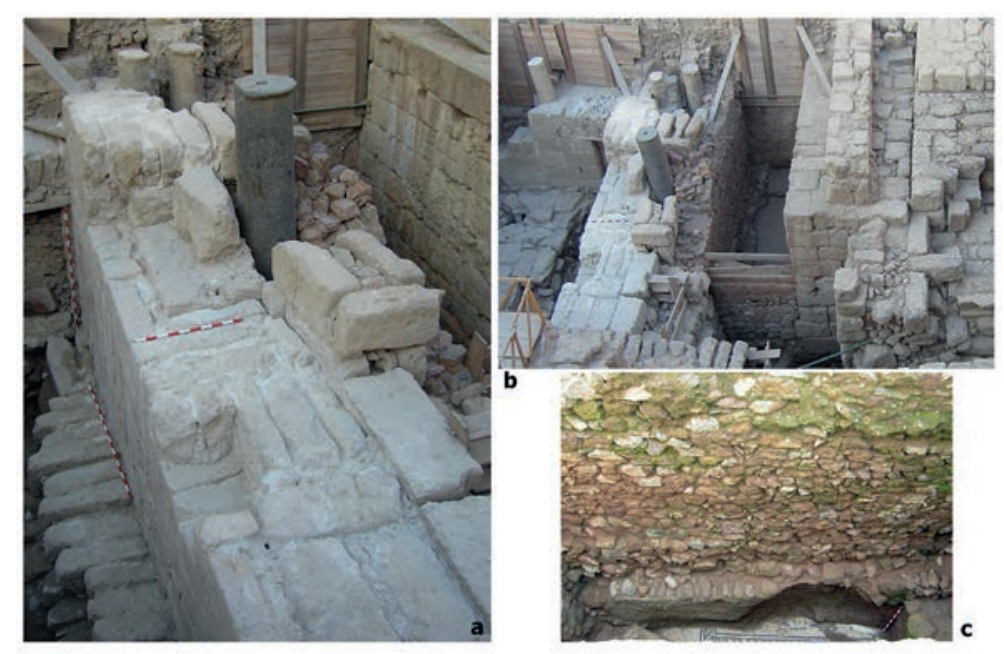

Figura 6. Patio de Mujeres del Alcázar de los Reyes Cristianos de Córdoba (fotografías del autor): a.- Detalle del paramento exterior de sillería; b.- Vista general de la estructura, donde se aprecian las dos técnicas empleadas en sendos paramentos; c.- Detalle del paramento interior de mampostería. 


\section{Aparejos de opus africanum o de encadenados verticales de sillería}

Además de estas construcciones oficiales vinculadas directamente con el poder emiral omeya, que por su entidad y especial funcionalidad de contención, nivelación y refuerzo de potentes estructuras presentan unos sistemas constructivos complejos, en varios puntos de la ciudad se han documentado igualmente estructuras con aparejos mixtos. Por lo que respecta a la técnica conocida como "opus africanum" o de encadenados verticales de sillería, en los últimos años se ha identificado en Córdoba un significativo repertorio de estructuras datadas en el siglo IX en las que se emplea este recurso constructivo con una calidad y entidad excepcionales, que definen un tipo arquitectónico muy regular y extendido en la ciudad omeya. Desafortunadamente, no siempre ha sido posible identificar la funcionalidad y características de los edificios de los que formaban parte dichas estructuras, cuyos cuidados aparejos muestran una alta pericia y cualificación técnica en la elaboración de estos muros.

Tomando como referencia el paramento interno del malecón descrito, aunque lógicamente a menor escala, ya se han publicado como emirales algunos edificios cordobeses, como la mezquita de barrio documentada en el trazado de la Ronda de Poniente, la circunvalación oeste de Córdoba, en el tramo conocido como Naranjal de Almagro, cuya técnica edilicia se ha identificado con la de pilares de sillería en forma de " $T$ " invertida que alternan con fábrica de mampostería (Murillo, Casal y Castro 2004: 267; Murillo et alii 2009-2010: 539). La diferente técnica constructiva detectada en la galería erigida en el extremo del patio opuesto a la sala de oración, permite interpretarla como una ampliación perteneciente a una fase posterior.

Igualmente conocido es el repertorio de técnicas constructivas empleadas en varios muros de cierre de una potente construcción documentada en el sector suroccidental de la ciudad, durante la excavación arqueológica en el Zoológico Municipal de Córdoba (Martín 2006), identificada con la almunia Balat Mughit. En las edificaciones adscritas a la fase de construcción y ocupación de la almunia en el siglo IX se generaliza el uso de sillería de gran módulo, junto al cual se distinguen dos tipos de variantes técnicas mixtas: un tipo de "construcción en damero", con sillería de calcarenita reutilizada intercalada con rellenos de mampostería de cantos; y otro que corresponde a un remedo del clásico opus africanum, con muros compuestos por pilares de sillería dispuestos en vertical que intercalan con cajeados de mampostería de calcarenitas bien careados (Ruiz Lara et alii 2008: 175-177) (Fig. 7a).

El ejemplo más espectacular de los documentados en fechas recientes es el muro excavado en la ampliación del Hospital La Arruzafa (en la esquina entre la C/ Poeta Valdelomar Pineda y la C/ Marino Alcalá Galiano), en el sector noroccidental de los arrabales de Córdoba. Esta estructura se extiende por varias decenas de metros por todo el solar en sentido este-oeste y define el cierre septentrional de una gran propiedad aristocrática del tipo conocido como "almunia", datada en época emiral ${ }^{13}$. Conserva un alzado de más de dos metros de altura, lo que permite apreciar con claridad sus características edilicias y su adscripción al tipo de técnica de opus africanum (Fig. 7b). Los pilares de sillería están formados por la superposición de grandes bloques de calcarenita dispuestos sobre la tabla, reutilizados de las estructuras de una antigua villa romana instalada en el solar, que ocupan toda la anchura del muro, de más de un metro de grosor, y separados a intervalos regulares de apenas un metro de distancia entre ellos. El relleno intermedio está compuesto por mampuestos de calcarenita de mediano tamaño, bien careados, trabados con tierra y sin apenas cal, formando cajones cuadrados que coinciden aproximadamente con la altura de los sillares. Esta misma técnica se emplea en los lienzos que definen los muros de un edificio situado al interior de dicho recinto, en cuya esquina se dispone una torre realizada con sillares almohadillados de acarreo. En este tramo se conserva parte del mortero que revestía los rellenos de mampostería (Fig. 7c).

La ubicación de esta construcción, en el entorno de la almunia de al-Rusafa, mandada erigir por el propio Abd al-Rahman I ( $c f r$. Murillo 2009), hace pensar en la entidad y el carácter aristocrático de esta propiedad, vinculada con algún alto dignatario de la corte omeya, que emplea esta técnica mixta para delimitar su perímetro exterior.

De una calidad similar, pero con los pilares dispuestos en posición vertical, son otras tres estructuras documentadas en varios puntos de la ciudad. En el entorno del antiguo anfiteatro romano de Córdoba, en la C/ Albéniz, ${ }^{\circ} 2$, se excavó un muro, datado en el siglo IX por argumentos estratigráficos, levantado con sillares de

\footnotetext{
13 Información facilitada por el arqueólogo don Rafael Clapés, a quien agradecemos los datos y la posibilidad de utilizar las fotografías tomadas durante nuestra visita a la excavación.
} 
calcarenita y con un sistema de cimentación que emplea una técnica identificada como "pseudoafricana" (Fig. $7 d$ ), cuyas características técnicas coinciden plenamente con los ejemplos que venimos recopilando: "alterna sillares colocados a modo de pilares interiores con paños de mampostería de mediano formato, muy bien trabada entre sí, cementada entre hilada e hilada con una argamasa muy arcillosa" (Ortiz Urbano 2009: 883). Los sillares colocados en vertical definen la anchura de la estructura $(0,55 \mathrm{~m})$ y entre ellos se disponen hiladas de mampostería irregular de tamaño medio bien trabadas entre sí con aglomerante de tierra vertido entre hiladas.

En el espacio intramuros de la medina, en las inmediaciones del solar ocupado por el teatro romano de la ciudad (C/ Antonio del Castillo, $\mathrm{n}^{\mathrm{o}} 3$ ), se ha documentado la estructura que, a nuestro juicio, mejor se ajusta al tipo arquitectónico de opus africanum, esto es, "la disposición de machones verticales de sillares reutilizados, separados entre sí a intervalos regulares, rellenando estos intervalos de mampuestos careados" (Ruiz Nieto 2009: 1194) (Fig. 7e). En este caso, el aparejo mixto corresponde al alzado de una estructura (de 7,20 de longitud conservada, por $0,60 \mathrm{~m}$ de anchura y $1,20 \mathrm{~m}$ de una potencia máxima conservada), apoyada sobre "un zócalo de dos hiladas de mampuestos que en el paramento Sur sobresalen ligeramente de la vertical del muro, mientras que en el paramento Norte no se aprecia este resalte" (Ruiz Nieto 2009: 1194). Esta estructura, fechada en época emiral, define la línea de fachada que separa las construcciones domésticas de la calle situada al norte y que marcará la orientación del resto de estructuras durante la etapa islámica. Sin embargo, no ha sido posible concretar la función del edificio, más allá de su carácter residencial, a pesar de la cuidada técnica con la que fue erigido.

La última de las construcciones que emplean un aparejo mixto similar a los descritos corresponde al tramo de muralla occidental de la medina, documentado en el seguimiento arqueológico de la construcción del "Garaje Alcázar"14. La base del paramento interior de la muralla, visible en una longitud de circa 22 metros, está realizada con un aparejo de opus africanum que, a su vez, se apoya sobre un basamento de sillares dispuestos a tizón. Sobre esta alineación se levanta el resto de alzado de la muralla, ligeramente retranqueada, ya de época

\footnotetext{
14 Parking la Mezquita de Córdoba, C/ Cairuán, nº 1. Vargas Cantos, S. 2012: Informe-Memoria del Seguimiento arqueológico en la U. A. 12 (Garaje Alcázar) del PEPCH de Córdoba (Parcela Catastral 32405/28). Informe administrativo inédito.
}

bajomedieval. Los sillares de la estructura (de más de 1 $\mathrm{m}$ de longitud por $0,60 \mathrm{~m}$ de anchura media), están dispuestos verticalmente, con una separación regular de un metro entre ellos. La particularidad del relleno es el empleo de abundante mortero de cal para su trabazón, hasta el punto de que el llagueado masivo cubre la mayor parte de los mampuestos (Fig. 7f) ${ }^{15}$. La documentación de esta estructura como consecuencia de un seguimiento de la obra, sin que haya sido posible realizar sondeos estratigráficos en su base, dificulta la asignación de una cronología precisa, pues no existen relaciones estratigráficas claras con niveles sedimentarios vinculados con este aparejo que aporten materiales que permitan aquilatar su datación. La cronología propuesta inicialmente retrasa la construcción de esta estructura "en un momento indeterminado del último tercio del siglo XII, por la similitud con el opus africanum islámico de este momento" ${ }^{16}$. No obstante, a tenor de los paralelos expuestos en este trabajo, todos los cuales se datan en el siglo IX, nos decantamos por esta cronología emiral, teniendo en cuenta también que el lienzo septentrional del alcázar, realizado con una fábrica califal íntegramente de sillería a soga y tizón, parece adosarse a esta estructura. No obstante, la existencia de forros internos de la muralla y añadidos posteriores impide apreciar las relaciones estratigráficas con absoluta certeza.

Como ya hemos indicado, las mayores analogías formales y técnicas de estos aparejos emirales cordobeses se encuentran en las construcciones emeritenses; en concreto, en los palacetes omeyas del área arqueológica de Morerías. En este caso, la secuencia estratigráfica asociada a estos edificios permite adscribir estas técnicas con seguridad a época emiral, entre finales del siglo VIII e inicios del siglo IX (Alba 2009: 411); en especial los paramentos de opus africanum con los que se levanta el denominado "Edificio C" (Alba 2009: 388, fig. 4 y 402-402, figs. 15 y 16) (Fig. 8). Estos aparejos "ortodoxos" de opus africanum se asientan sobre un basamento de sillares de granito reutilizados dispuestos a tizón y en ellos se emplea abundante cal para trabar la mampostería. Estos ejemplos han llevado a reconsiderar la tradicional atribución de estas construcciones a etapas previas a la presencia islámica, y obligan a "romper con esquemas rígidos de interpretación que lleven a descartar la evidencia, por ejemplo, de que un derrumbe de

\footnotetext{
Este mismo tipo de revestimiento se aprecia en el edificio situado al interior del recinto de la almunia de la Clínica Arruzafa.

16 Vargas Cantos 2012: 11
} 

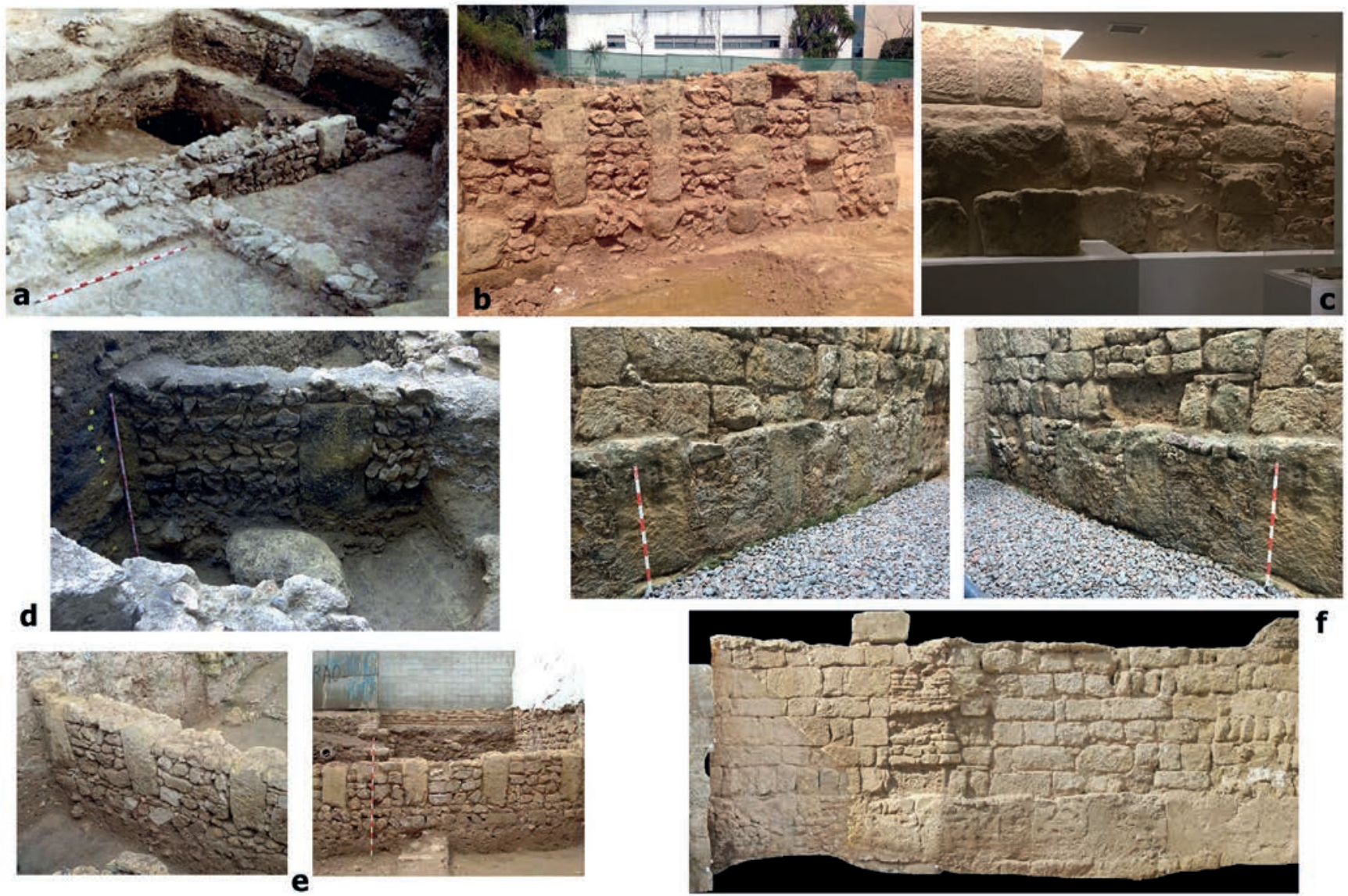

Figura 7. Aparejos con la técnica de encadenados verticales de sillería de época emiral en Córdoba: a.- Zoológico Municipal de Córdoba (Ruiz Lara et alii 2008); b y c: Hospital La Arruzafa, (esquina entre la C/ Poeta Valdelomar Pineda y la C/ Marino Alcalá Galiano) (fotografías del autor); d.C/ Albéniz, no 2 (Ortiz Urbano 2009); e.- C/ Antonio del Castillo, no 3 (Ruiz Nieto 2009: 1194); f.- Parking la Mezquita de Córdoba, C/ Cairuán, no 1 (alzado tomado de Vargas 2012 y fotografías del autor).

tegulae, un muro de africanum o un pavimento de opus signinum puedan ser emirales" (Alba 2009: 393). De hecho, como hemos intentado mostrar en esta sucinta recopilación, estos aparejos son muy habituales en la arquitectura emiral en la capital andalusí omeya.

B. Pavón recopila un catálogo de estructuras en las que se emplea la técnica de opus africanum o "pilares de refuerzo en muros de mampostería", para las que propone una cronología genérica "romano-árabe" (Pavón 1999: 591 y 604); si bien la mayoría de ellas corresponden a época romana. No obstante, destaca la mención a las mezquitas de Qayrawan y Susa y al ribat de Monastir, todos ellos de época aglabí, coincidente, por tanto, con la datación emiral omeya que estamos proponiendo para los ejemplos cordobeses.

Los aparejos documentados en la Calle de la Plata, $\mathrm{n}^{0} 6$ de Toledo ${ }^{17}$, que definen la fachada del edificio

$17 \mathrm{http}: / /$ www.consorciotoledo.org/en-un-callejon-sin-salida-ii/ (como en el C/ Antonio del Castillo, $\mathrm{n}^{\mathrm{0}} 3$ de Córdoba vid. supra), presentan ciertas analogías con los aparejos descritos hasta ahora. Sin embargo, en este caso los argumentos para asignarle una cronología recurren a las construcciones de época romana y la proximidad de este muro a las estructuras interpretadas como pertenecientes a la natatio de unas termas. Otro aparejo toledano similar se localiza en el ábside de la iglesia de San Vicente ${ }^{18}$.

En el área del sureste y levante se han interpretado como "aparejos que recuerdan al opus africanum" algunas soluciones arquitectónicas documentadas en edificios emirales de Murcia y Tolmo de Minateda,

\footnotetext{
18 La orientación del ábside de la iglesia de San Vicente, una de las más antiguas de la ciudad, muy similar al de algunas estructuras romanas del entorno del foro, y sus analogías con las técnicas de la basílica de Baelo Claudia, han sido los argumentos utilizados para plantear la posibilidad de que el templo toledano pudiera haber reaprovechado las estructuras de la basílica romana (Ruiz Taboada y Azcárraga 2016: 276-277). Imágenes del ábside se pueden contemplar en la página web: http://ciudaddelastresculturastoledo.blogspot. com.es/2015/06/opus-africanum-pies-de-gigante-en-las.html
} 


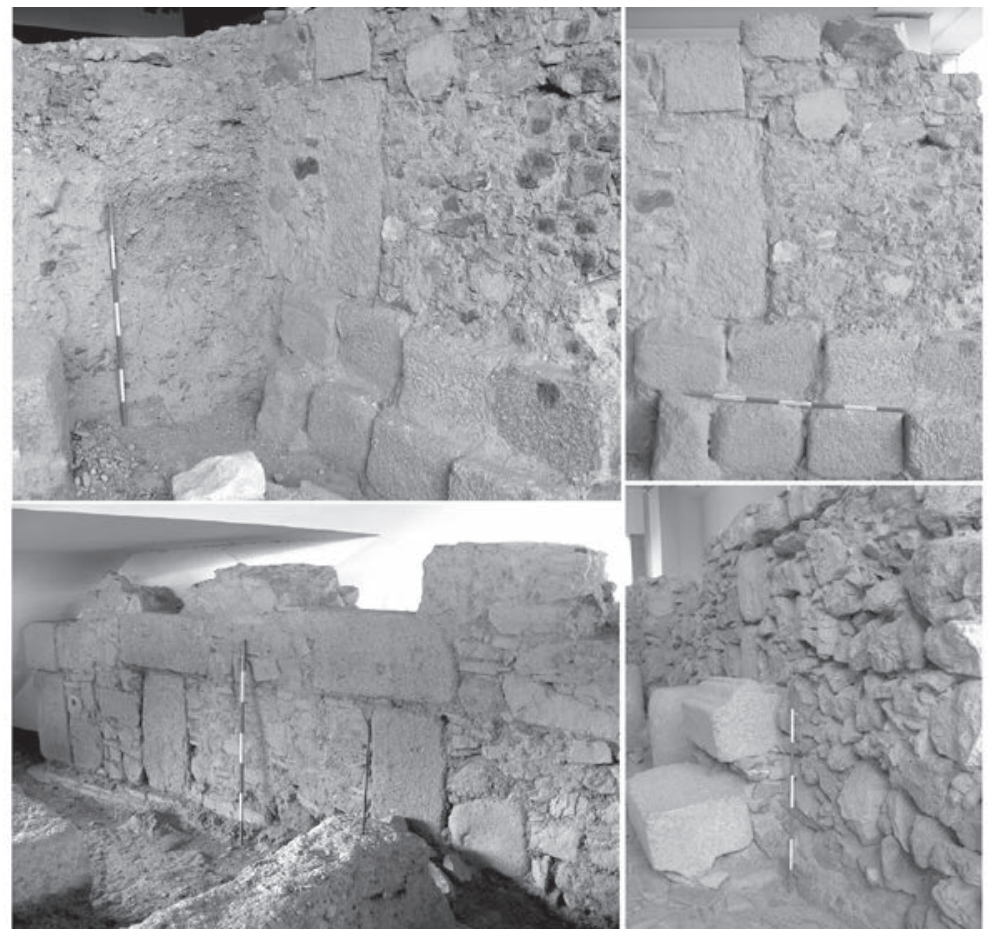

Figura 8. Repertorio de aparejos documentados en los palacetes omeyas del área arqueológica de Morerías (Alba 2009: figs. 4, 12, 15 y 16).

consistentes en el empleo de sillares de calcarenita dispuestos verticalmente como refuerzo en jambas y esquinas (Navarro y Jiménez 2011: 95). Mucho más claros son los aparejos documentados en la Almoina de Valencia, en concreto, en las estructuras interpretadas como parte de un posible barrio artesanal de época omeya (siglos IX-X), formado por varios cuerpos de estancias de pequeño tamaño y disposición muy regular, realizados con técnicas constructivas bastante uniformes. Nos interesa destacar especialmente los tramos en los que "se emplea una fábrica irregular que integra sillería y material diverso de cantería sin concertar" (Martí y Pascual 2000: 508 y 533, fig. 5). Los sillares empleados son material de acarreo y la disposición vertical de los bloques permite su clara identificación como opus africanum. La homogeneidad de las construcciones, tanto de las estancias como de las fábricas, parece estar indicando su pertenencia a un proyecto común, probablemente bajo una promoción "pública" u oficial.

\section{Aparejos en damero}

La nómina de técnicas mixtas de piedra se complementa con un tercer tipo en el que alternan bloques de sillería con rellenos de mampostería, pero en este caso no con pilares o encadenados verticales, sino con la particularidad de que los bloques de sillar se alternan en el alzado con cajones de mampostería a la manera de huecos cuadrangulares rellenos. En esencia, los sillares deberían desempeñar por sí mismos la función de elementos portantes, de tal forma que el relleno de mampuestos podría ser suprimido sin debilitar la estabilidad de la construcción (cfr. Adam 1996: 129-131). El resultado es una singular alternancia que recibe el nombre de "aparejo en damero"; también conocido como "ajedrezado", por la similitud en la alternancia de casillas de un tablero de ajedrez. Se trata de una solución arquitectónica que supone un cierto ahorro de costes en el número de sillares labrados y el aprovechamiento de los restos de talla para el relleno, pero que requiere de una labra cuidada de los sillares para establecer un módulo regular adecuado para garantizar la estabilidad de la estructura.

Existe un amplio elenco de aparejos de este tipo en edificios de cierta entidad arquitectónica distribuidos en el entorno suburbano de Córdoba, englobados bajo el término genérico de "almunias". No obstante, el estado de conservación de muchas de las estructuras documentadas, tanto de época emiral como califal, dificulta la correcta e incuestionable identificación de la técnica edilicia empleada. Es decir, en más de un caso la existencia de aparejos mixtos en los que alternan sillares y mampuestos en la única hilada de alzado conservada se ha interpretado como la técnica de opus africanum, cuando, en realidad, pudiera tratarse del tipo de aparejo 
en damero. Un indicio que pudiera estar indicando el empleo de esta última técnica parece ser la disposición de los sillares a soga y tizón, sin que se coloquen los bloques en vertical. Pero, en el estado actual de nuestros conocimientos, no parece una tarea fácil la discriminación en cada caso.

Del repertorio que hemos seleccionado, el ejemplo ya publicado corresponde a uno de los muros que delimitaban el recinto exterior de la gran propiedad vinculada con la almunia al-Rusafa (León 2008: 63, lám. 3; Murillo 2009: 461, lám. 59a), documentado durante un control arqueológico de la zona del Tablero Bajo, en el sector noroeste de Córdoba, en las inmediaciones de la antigua Huerta de la Arruzafa ${ }^{19}$. Desconocemos las técnicas constructivas con las que se levantó el edificio principal, aún no excavado, pero localizado mediante prospecciones geofísicas, gracias a las cuales se ha podido identificar el diseño de su planta, que remite a claros modelos orientales (Murillo 2009). La técnica constructiva del muro exterior combina la sillería de gran formato, con la que se levantan las dos torres o contrafuertes documentados, y el aparejo mixto, en el que grandes bloques de sillería de calcarenita dispuestos a tizón alternan con estrechos espacios rellenos con mampuestos de calcarenita de mediano tamaño (Fig. 9a). La estrechez de los espacios de mampostería, de entre $0,40-0,50 \mathrm{~m}$, hace que nos decantemos por la identificación como aparejo en damero, en lugar del opus africanum. Esta interpretación parece confirmarse con las características del paramento interno (occidental), en el que se conservan dos hiladas en las que se aprecia la alternancia vertical entre rellenos de mampostería y sillares dispuestos a soga (Fig. 9b). Las estructuras que ahora nos ocupan han sido interpretadas como pertenecientes a una fase emiral sucesiva a la fundación de la almunia al-Rusafa (Murillo 2009: 461), probablemente relacionada con las reformas acometidas en época de Muhammad I (León 2008: 63).

Igualmente se ha datado en época emiral un edificio excavado en los arrabales de poniente, en la Parcela 2 del $\mathrm{PPO}^{20}$. De este edificio se han documentado solo tres espacios delimitados por potentes muros que en época califal fueron aprovechados para levantar una vivienda y una zona de servicio. Las construcciones de la fase emiral se levantan alternando sillares dispuestos

\footnotetext{
19 Agradezco al Dr. Murillo el material gráfico utilizado en este trabajo.

20 Molina Expósito, A. 2007: Informe y memoria de la Actividad Arqueológica Preventiva de la Manzana 2 del Plan Parcial O-7 de Córdoba. Informe administrativo depositado en la Delegación de Cultura de Córdoba (inédito).
}

a soga y apoyados sobre la tabla, cuya anchura marca el grosor de las estructuras, y rellenos de mampuestos de calcarenita trabados con tierra (Fig. 9c).

A este mismo tipo corresponden algunos de los muros que delimitaban diferentes espacios de la gran almunia excavada en las naves municipales de la zona de Fontanar de Cábanos (junto a C/ Dr. Gonzalo Miño Fugarola). Este edificio, organizado en torno a tres grandes patios, contaba con un baño privado revestido de losas de mármol y una posible mezquita privada, dando muestra de la entidad del complejo arquitectónico en torno al cual acabó conformándose un arrabal andalusí. Los sondeos abiertos durante la intervención preventiva inicial permitieron datar en época emiral el origen de este edificio ${ }^{21}$. A esta fase de configuración inicial se adscriben algunas de las alineaciones maestras que definen los espacios. Estos muros están levantados con una técnica muy similar a la anteriormente descrita; es decir, sogas de sillería que ocupan la anchura del muro que alternan con rellenos de una mampostería muy regular. En la zona más próxima al baño, en el sector occidental del conjunto (Fig. 9d), los mampuestos están compuestos por cantos de río; mientras que en la zona oriental, al norte del patio principal, en otro de los muros que muestra la misma técnica, los rellenos están formados por mampuestos de calcarenita bien regularizados (Fig. 9 e y f).

El ejemplo más reciente en el que se ha documentado con claridad la técnica de damero corresponde al edificio singular excavado en la Parcela 16A del Plan Parcial PPO7 (C/ Escritora María Goiry). Este edificio se ha fechado en una una fase emiral, pues queda completamente cubierto por el desarrollo de un arrabal de época califal, para el que se reutilizan algunas de sus estructuras que coinciden con las nuevas alineaciones. Esta circunstancia ha condicionado la visibilidad del edificio emiral, del que en algunos puntos solo perdura la cimentación de cantos rodados. Los escasos alzados conservados de este complejo arquitectónico muestran una alternancia de muros realizados con el clásico aparejo de sillería a soga y tizón con otros levantados con aparejos mixtos en damero (Fig. 9g). En estos últimos la anchura de las estructuras está definida por el grosor de dos sillares dispuestos a soga en sendas caras del muro

\footnotetext{
21 AA. VV. 2004: Informe de resultados preliminares. Intervención Arqueológica de Urgencia Edificio de usos múltiples del Área de Infraestructuras del Ayuntamiento de Córdoba. El Fontanar, Parque Cruz Conde (CÓRDOBA). Parcelas catastrales 20298/12 y 20298/13 (Calificación PGOU: SGS SUNP1/PAU SC-1). Informe administrativo depositado en la Delegación de Cultura de Córdoba (inédito), Córdoba.
} 
y el relleno intermedio está formado por mampuestos de calcarenita muy bien regularizados y careados. La identificación de la técnica de damero ha sido posible en este caso, de forma excepcional, porque sobre uno de los casetones de mampuestos se ha conservado el arranque de un nuevo sillar de calcarenita que lo encajaba (Fig. 9h). En el sector meridional del solar se han identificado algunos tramos con una técnica similar; pero en este caso corresponden a refacciones de época califal, que se distinguen de las anteriormente descritas porque apoyan sobre algunos paquetes sedimentarios posteriores y por la propia disposición de los mampuestos del relleno intermedio.

Hasta el momento, en todo el territorio peninsular son escasas las estructuras islámicas en las que se documenta esta técnica mixta. En el sur de Portugal se aprecia un precedente en época tardoantigua en el muro exterior que soporta el criptopórtico de Mértola (León 2003: 152), en el que la alternancia entre sillares de granito y mampuesto se realiza con ritmo irregular, pudiendo hablar de un trasunto de esta técnica de damero más que de un modelo canónico. Un remedo de dicha técnica, muy similar a la portugesa descrita, se encuentra en el recinto amurallado de Gafiq, en la actual población cordobesa de Belalcázar, pertenecientes a la fase datada en época emiral (León 2003: 140-144).

El ejemplo quizás más relevante por su estado de conservación es el recrecimiento de algunos tramos de la muralla de Coria (Cáceres) en los que sobre un paramento de sillares de granito se dispone un tramo conformado por una alternancia de estos bloques graníticos con rellenos intermedios formados por estrechos mampuestos de pizarra (Fig. 10 a y b). En otros puntos este relleno se realiza con ladrillos; aunque en este caso
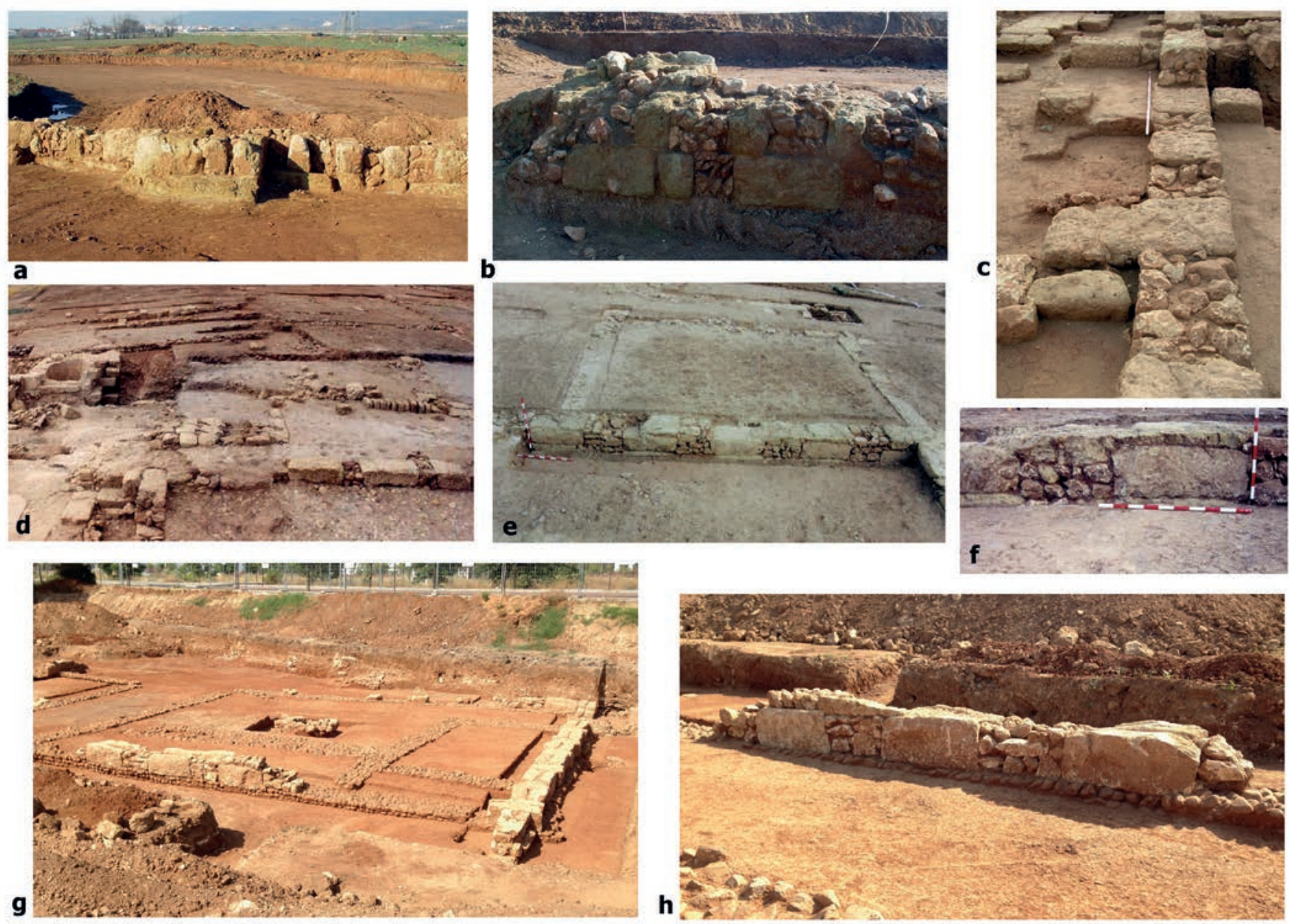

Figura 9. Aparejos en damero de época emiral documentados en Córdoba: a y b.- Paramentos externo e interno, respectivamente, del muro documentado en la zona del Tablero Bajo en las inmediaciones de la antigua Huerta de la Arruzafa (fotografías Juan F. Murillo); c.- Parcela 2 del PPO7 (Molina 2007); d, e y f.- Gran almunia excavada en las naves municipales de la zona de Fontanar de Cábanos (AA. VV. 2004; (c) GMU-UCO); g y h.- Parcela 16A del Plan Parcial PPO7 (C/ Escritora María Goiry) (fotografías del autor). 
parece resultado de una reparación posterior. Sin embargo, la adscripción cronológica de esta muralla es objeto de debate entre los autores que le atribuyen un origen bajoimperial y aquellos que consideran los paramentos de esta muralla como representativos de las construcciones emirales de la Marca Media de al-Ándalus ( $c f r$. León, en prensa). Al margen de esta discusión, aún no cerrada, sobre el arranque del recinto amurallado, los paramentos a los que nos referimos, situados en las partes superiores de los muros entre la Puerta de la Guía y la de San Pedro, parecen corresponder a algunas remodelaciones de época emiral-califal omeya (Espada 2011: 71); en especial, durante la segunda mitad del siglo IX, momento en el que se pudo llevar a cabo la reparación de las defensas de la ciudad frente a las incursiones cristianas en la zona (Espada 2011: 64). Para acometer estas obras se emplean técnicas islámicas, entre las que se considera la utilización de spolia.

Otro recinto amurallado en el que se identifican algunos tramos con un aparejo similar es el de Carmona (Sevilla). Las defensas de esta ciudad han sido objeto de numerosas reparaciones a lo largo de toda la Edad Media, por lo que se combinan tramos con diferentes técnicas constructivas en los que se reutilizan materiales edilicios de fases precedentes, como los sillares de "piedra alcoriza", una arenisca local. La mayoría de los lienzos muestran una base de sillares sobre los que se alzan los encofrados de tapial almohades (Valor 2014:
195). No obstante, en las hiladas inferiores de algunos lienzos $^{22}$ se aprecian paramentos que alternan bloques de sillería con rellenos compuestos por mampuestos de arenisca y ladrillos, cuyas gruesas juntas muestran el mortero de cal con el que están trabados (Fig. $10 \mathrm{c} \mathrm{y} \mathrm{d).}$ Si bien una primera interpretación para esta alternancia considera que son recalzos con los que se rellenan los espacios dejados tras la extracción de los sillares originales (Valor 1997: 606), las evidentes semejanzas con los ejemplos mencionados nos llevan a pensar que los lienzos de Carmona corresponden a una fábrica única y sincrónica. Los alzados de tapial se atribuyen a época almohade, mientras que la cronología propuesta para estas hiladas inferiores de piedra las lleva a época omeya, entre los siglos IX y X (Valor 1997: 611). A tenor de lo visto hasta ahora, coincidimos con esta datación en época omeya, sin que podamos aquilatar más la fecha.

\section{APAREJOS MIXTOS DE ÉPOCA CALIFAL EN CÓRDOBA}

Con la instauración del califato se produce una estandarización de los procedimientos constructivos en las obras oficiales omeyas, cuya más conspicua y conocida

\footnotetext{
22 Tramos con estos aparejos se localizan en la C/ Bodeguilla y en el lienzo localizado entre las calles Barranquillo y la Puerta de Córdoba (Valor 1997).
}

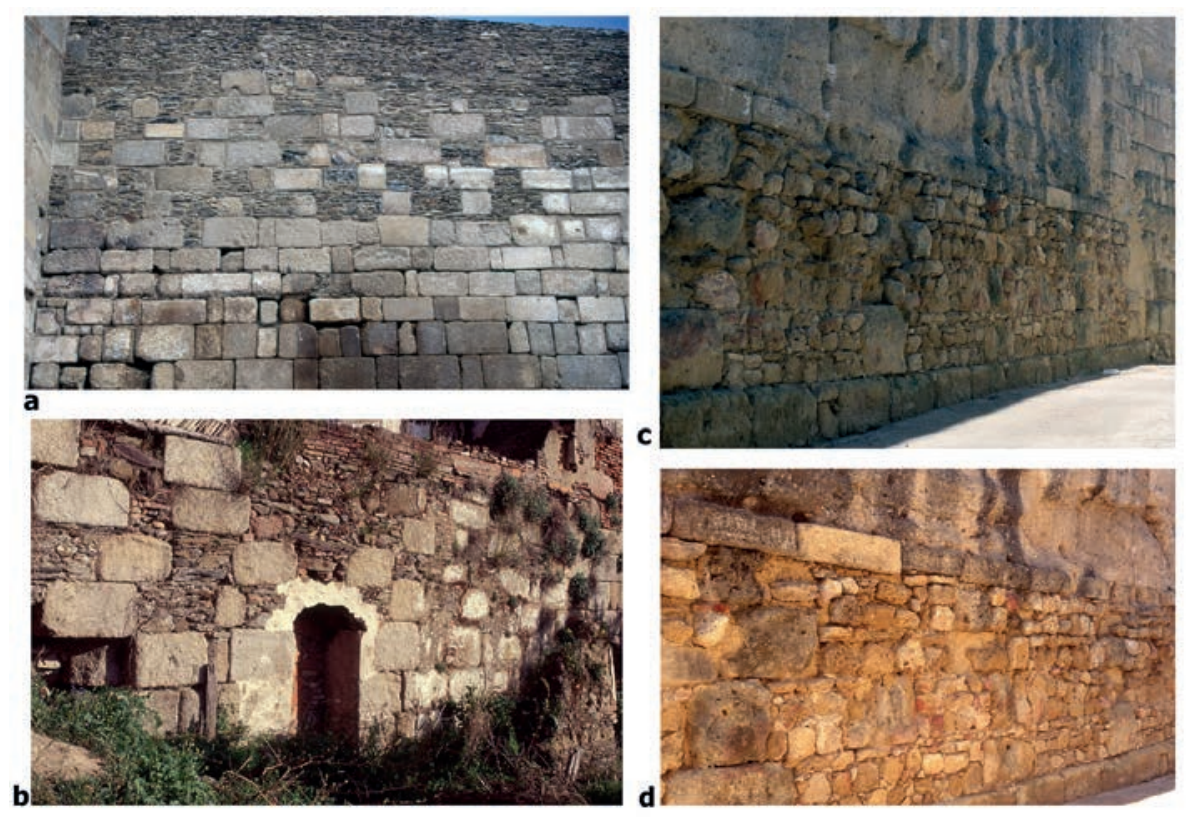

Figura 10. Aparejos en damero en al-Ándalus: a y b.- Coria (Cáceres); c y d.- Muralla de Carmona (Sevilla) (fotografías del autor). 
materialización se encuentra en la ciudad palatina de Madinat al-Zahra, donde se aplica un amplio repertorio de aparejos a soga y tizón (Vallejo 2010: 295). A pesar de ello, se mantienen algunas de las técnicas que hemos detectado en la Córdoba emiral, opus africanum - $\mathrm{O}$ encadenados verticales - y aparejo en damero, con las que se levantan estructuras de gran entidad en las que se alcanza una mayor pericia técnica.

\section{Aparejos de opus africanum o de encadenados verticales de sillería}

El repertorio de estructuras de época califal realizadas con esta técnica mixta parece reducirse significativamente. Además, las construcciones documentadas cuentan con las mismas limitaciones enunciadas con anterioridad, es decir, no conservan alzados suficientes como para poder catalogarlas como tales con seguridad, pues la simple alternancia de sillería y mampostería no indica necesariamente la adscripción a este tipo constructivo.

El único ejemplo que sí podemos incluir como una variante de esta modalidad de aparejo mixto se documenta en los suburbios orientales de la ciudad; en concreto, en la Parcela 1.1. F3 de la Avda. de Libia (Penco 2017). Se trata de una estructura aparentemente aislada que no define un recinto concreto; es decir, no estaba inserta "en una zona edificada", sino que el contexto es descrito como "una zona muy abierta", vinculada con actividades de regadío (Penco 2017: 1674). El muro excavado se conserva únicamente en un pequeño tramo de unos 5 metros de longitud y unos 1,20 m de anchura. La técnica con la que está realizado consiste en una cimentación de sillares atizonados, sobre los cuales se disponen dos parejas de sillares colocados a tizón separados entre sí a intervalos de más de $1,50 \mathrm{~m}$, con relleno intermedio de mampostería de guijarros y calcarenita bien careada (Fig. 11a). Las características de los materiales asociados a esta estructura permiten fechar su construcción a mediados del siglo X. Aunque su excavadora no ha podido precisar su funcionalidad, plantea la posibilidad de que "se utilizase como muro de contención" (Penco 2017: 1674).

Pese a lo limitado de la muestra, las características técnicas y el contexto en el que parece insertarse esta estructura remiten, salvando las evidentes distancias, a un enclave bien conocido de época califal, en concreto, durante el califato de al-Hakam II: la almunia de al-Rumaniyya. De esta explotación se conserva en su lado occidental un amplio tramo del muro que delimita el recinto exterior y las terrazas de cultivo. Esta potente estructura se levanta con una singular técnica mixta, consistente en una base de sillares de calcarenita dispuestos a soga y tizón, sobre la que se levantan una serie de pilares de sillería en los que alternan de forma muy regular hiladas a soga con otras atizonadas, cuyo relleno, que lo distingue del resto de construcciones descritas hasta ahora, se realiza con encofrado de tapial (Fig. 11b).

De considerar la posibilidad de estas analogías, el muro documentado en los arrabales surorientales de Córdoba podría haber formado parte de un recinto vinculado con una propiedad agropecuaria, lógicamente de mucha menor entidad.

En otros sectores de los arrabales califales se han identificado aparejos mixtos, como decíamos, catalogados como "opus africanum", sin que pueda confirmarse la idoneidad de tal denominación.

Este es el caso del muro documentado en la $\mathrm{C} /$ Músico Infantas, 1; una potente estructura que marca la alineación de los espacios del arrabal "realizada en opus africanum" (Palomino 2009: 892). La entidad arquitectónica y la singularidad técnica ha llevado a considerar su ejecución como consecuencia de una posible promoción oficial o, al menos, comunitaria.

Algo parecido sucede con varias de las estructuras vertebradoras del sector excavado en la Carretera de Trassiera. Por un lado, en el interior del edificio interpretado como una almunia excavado en el sector central (margen septentrional de la Carretera de Trassierra - en el denominado PERI MA-9-), uno de los muros que delimita una de las estancias "presenta técnica edilicia de tipo opus africanum romano, donde entre tongadas de mampuestos y ripios careados se colocan pilares realizados con sillares escuadrados de calcarenita y por tramos presenta contrafuertes" (Rodero y Asensi 2006: 319). De este mismo sector, en este caso en la intersección de la carretera de Santa María de Trassierra y la Avenida Cañito Bazán de Córdoba se documentaron varios muros con técnicas mixtas (Fig. 11c). Algunos delimitaban espacios funerarios de la zona residencial (Rodero y Molina 2006: 227); otras dos potentes estructuras de grandes dimensiones y longitud, "previsiblemente califales" delimitaban al oeste y sur un gran espacio abierto situado junto a un camino y al norte del cauce de un arroyo. Estas construcciones están realizadas "con mampuestos careados imitando la técnica del opus africanum romano, donde entre tongadas de mampuestos y ripios careados se colocan pilares realizados con sillares escuadrados de calcarenita que en su lado Este y por tramos presenta contrafuertes" (Rodero y Molina 2006: 242). 

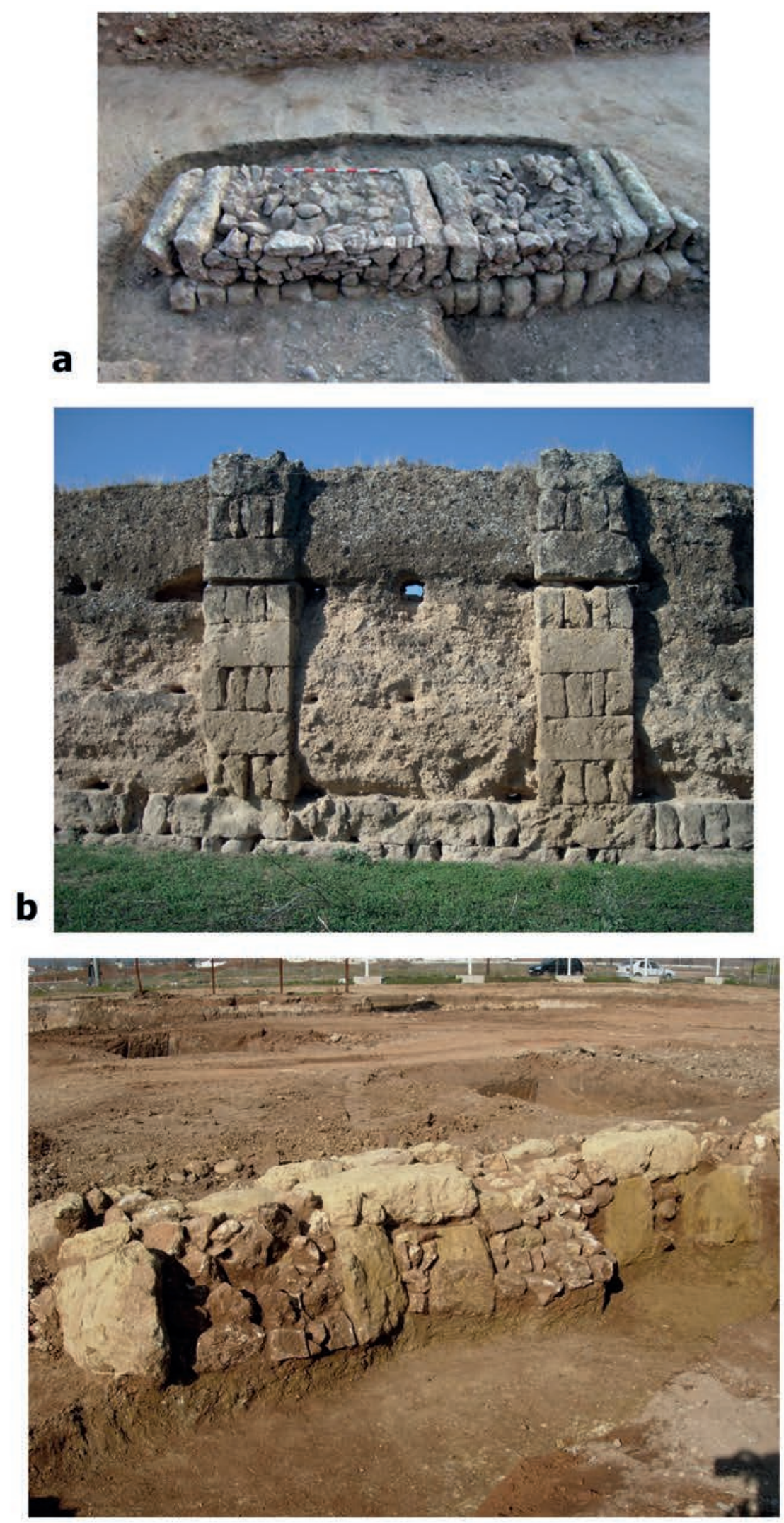

C

Figura 11. Aparejos de opus africanum de época califal en Córdoba: a.- Parcela 1.1. F3 de la Avda. de Libia (Penco 2017); b.- La almunia de alRumaniyya (fotografía del autor); c.- Santa María de Trassierra y la Avenida Cañito Bazán de Córdoba (fotografía Juan F. Murillo). 
La genérica descripción de estos recursos constructivos y el estado de arrasamiento de las estructuras no permiten identificar con claridad la técnica empleada, pudiendo corresponder, en realidad, al tipo de aparejo alterno ajedrezado. Como ya hemos comentado, no resulta extraña la combinación de varios tipos de fábricas en los mismos conjuntos arquitectónicos.

La presencia de este tipo de solución arquitectónica mixta en piedra es poco habitual en otras zonas de alÁndalus o, al menos, no han sido sistematizadas como ha sucedido con las fábricas hormigonadas. No obstante, se han podido localizar algunos ejemplos de muros que presentan cadenas de sillares como elementos vertebradores de las estructuras. Este es el caso del potente muro excavado en la C/ Imperial ( $\mathrm{n}^{\circ}$ 41-45) en Sevilla ${ }^{23}$, que marca el cambio en la organización urbanística de este sector de la ciudad y define la nueva alineación de las casas y el viario (como se aprecia en los muros emirales de la $\mathrm{C} /$ Antonio del Castillo n ${ }^{\circ} 3$, de Córdoba, vid. supra). En esta estructura se han podido distinguir dos fases: la más antigua, correspondiente a los siglos IX-X (época emiral-califal, ¿post. 914?) se aprecia un aparejo mixto en el que se emplean sillares, probablemente reutilizados de la muralla romana, que alternan con ladrillos y mampuestos; la segunda fase (postcalifal), datada en el s. XI, supone un recrecido del anterior, formado por un muro que marca la medianera entre dos viviendas, realizado con un aparejo que podría ser calificado como opus africanum, formado por encadenados de sillares verticales que separan paños de ladrillo romano reutilizado bien aparejado (Tabales 2001: 421-422). Por tanto, parece mantenerse en Sevilla, lógicamente adaptado a la disponibilidad de materiales, este tipo de técnica mixta en época islámica (Tabales 2000: 1079).

Una fábrica mixta muy peculiar es la documentada en varios paños de la muralla de Almería, consistente en fábrica hormigonada con tapiales que cuentan con pilares o cadenas verticales de sillares (de unos $0,60 \mathrm{~m}$ de anchura) dispuestos a intervalos regulares (separados entre sí unos $2 \mathrm{~m}$ ), pero embutidos en el núcleo de los muros $\mathrm{y}$, por tanto, inicialmente ocultos a la vista (Gurriarán 2018: 328 y 432) ${ }^{24}$. La cronología califal de estas fábricas se ha podido determinar a partir de la lectura estratigráfica de los paramentos de la muralla y por las analogías con las técnicas documentadas en la

\footnotetext{
23 Agradezco la información facilitada por el Dr. Miguel Ángel Tabales.

24 Gurriarán, P. 2018: La arquitectura del poder en la frontera Sur de alAndalus durante el Califato de Córdoba. Tesis doctoral inédita. Universidad de Sevilla.
}

arquitectura doméstica de la vecina ciudad de Pechina, consistentes en cajones de tierra apisonada con refuerzos de lajas y sillares en las esquinas o en las jambas (Gurriarán 2018: 436).

Aunque sobrepasa el ámbito cronológico que estudiamos en este trabajo, se ha documentado un muro levantado con la técnica mixta de opus africanum en un sector de arrabal de época almohade, excavado junto al solar en el que se emplazó el antiguo anfiteatro romano (C/ Secretario Carretero, esquina con C/ Antonio Maura). Las casas de dicho arrabal combinan los aparejos mixtos con encofrado de tapial, algunos de cuyos paramentos aún mantenían revestimientos decorados con pinturas en rojo y blanco (Castillo 2008: 67). El aparejo mixto se formaba por bloques de sillería colocados verticalmente cuyo relleno estaba compuesto por mampuestos de calcarenita y cantos de pequeño tamaño dispuestos en espiga y trabados aparentemente con tierra y escasa cal (Fig. 12) ${ }^{25}$. Todas las estructuras excavadas forman parte de las viviendas de uno de los arrabales que durante un breve periodo de tiempo (entre la década de 1170 y 1190) se extendieron por los suburbios de la ciudad almohade que experimentó un efímero proceso de revitalización urbana ( $c f r$. León y Blanco 2010). Por tanto, en este caso, el empleo del opus africanum no parece tener ninguna connotación funcional especial y constituye una excepción en el panorama arquitectónico local.

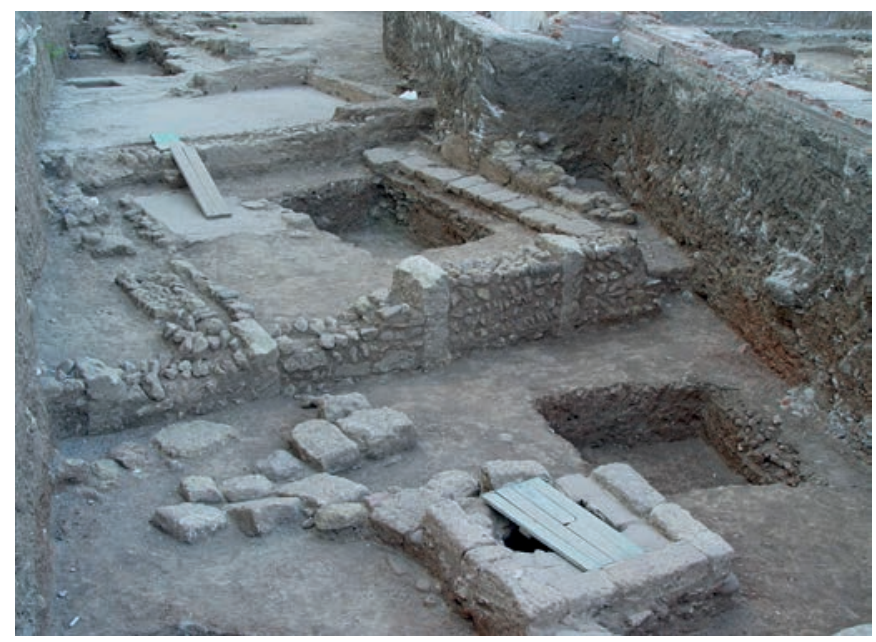

Figura 12. Estructuras levantadas en opus africanum en la C/ Secretario Carretero, esquina con C/ Antonio Maura (fotografía de Juan F. Murillo).

\footnotetext{
25 Las analogías con estas fábricas llevaron a considerar como posiblemente almohades los paramentos documentados en la muralla del Garaje Alcázar (Parking Mezquita) (vid. supra).
} 


\section{Aparejo en damero}

Durante el siglo $\mathrm{X}$ parece perdurar esta técnica sin grandes modificaciones. Los testimonios documentados proceden, en la mayoría de los casos, de edificios de notable entidad arquitectónica, en especial, mezquitas y algunas construcciones civiles de especial relevancia.

En ocasiones se constata como solución en las hiladas pertenecientes a la cimentación, como sucede en la mezquita conservada en el antiguo convento de Santa Clara, datada a finales del siglo $\mathrm{X}$, donde se conserva una hilada en la que alternan sillares a tizón con rellenos intermedios de mampostería irregular (Marfil 2002: 269) (Fig. 13 a y b).

En los alzados documentados se mantiene el mismo esquema que ya expusimos para construcciones de época emiral. Además de las reformas mencionadas en la almunia de la Parcela 16A del Plan Parcial PPO7 (Fig. 13c), los rellenos de mampostería entre cajones de sillería se documentan en varios edificios de los arrabales cordobeses.

En la arquitectura residencial contamos con una muestra en una de las casas excavadas en el solar de la actual Estación de autobuses, donde "la técnica constructiva utilizada en la edificación de los muros exteriores combina la mampostería con el empleo de sillares" (Carmona 1997: 216). Este aparejo, visible en la planta del muro oriental de la casa (Carmona 1997: figs. 1 y 3) se combina con otros que emplean una solución constructiva también habitual en muros de casas califales, consistente en cajas formadas por pares de sillares dispuestos a soga delimitados por otros colocados a tizón, cuyo interior se rellena de cantos rodados y tierra (Carmona 1997: 216).

En construcciones de carácter religioso contamos con un ejemplo de mezquita califal cuyos muros se levantan, al menos en las hiladas conservadas, con aparejos en damero. En la conocida como mezquita de Fontanar se pudieron individualizar varios tipos de aparejos califales ${ }^{26}$ en distintos tramos de los muros perimetrales, pese al nivel de arrasamiento de las estructuras y el intenso expolio

\footnotetext{
26 La cronología califal viene avalada por la secuencia estratigráfica, ya que la zanja de cimentación de la mezquita se excava en un estrato emiral (Luna y Zamorano 1999: 149)
}
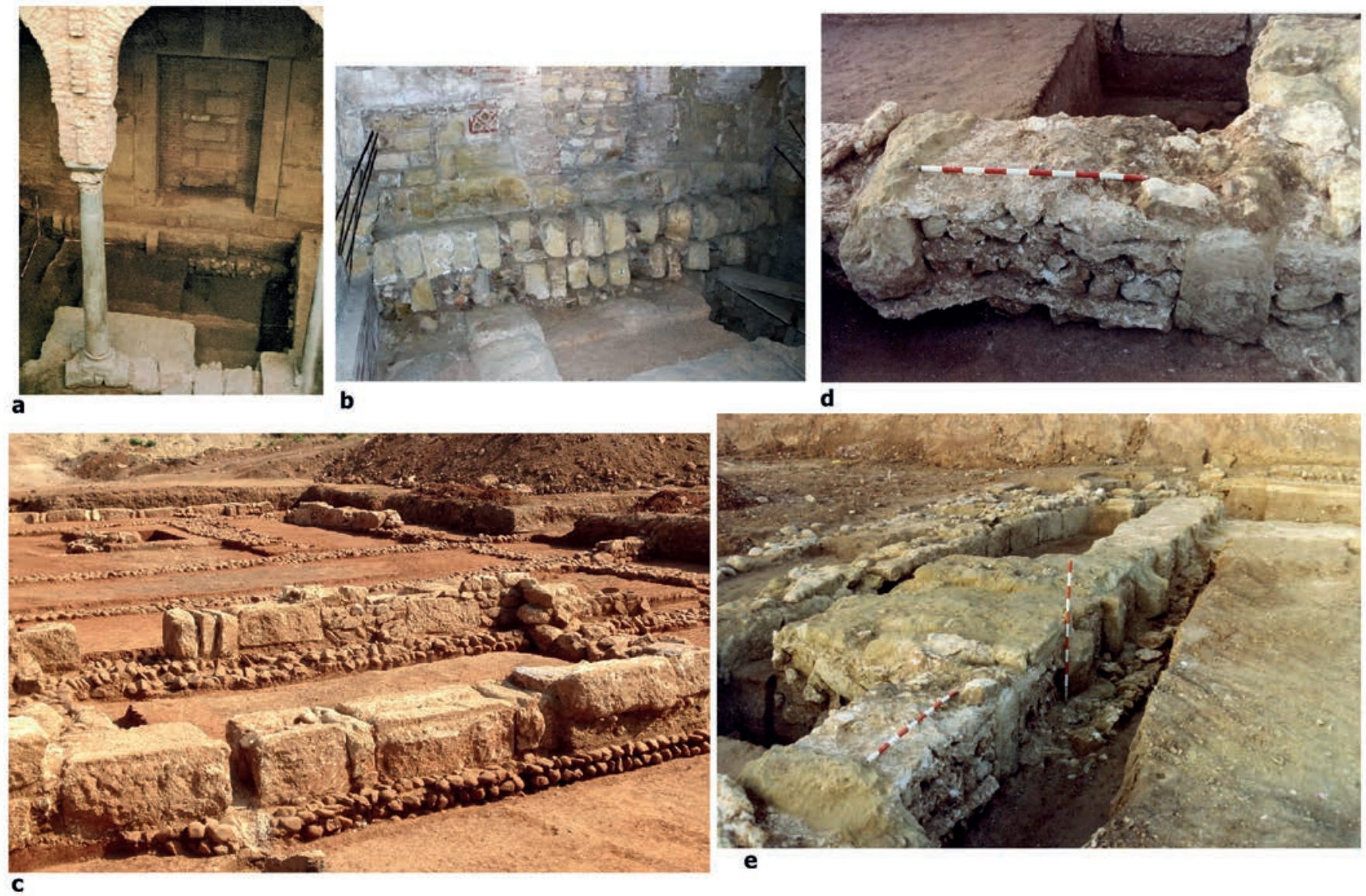

Figura 13. Aparejos en damero de época califal en Córdoba: a y b.- Mezquita del antiguo convento de Santa Clara (a.- Marfil 2002; b.- Fotografía del autor); c.- Parcela 16A del Plan Parcial PPO7 (fotografía del autor); Mezquita de Fontanar (fotografías aportadas por Ana Zamorano). 
al que fue sometido el edificio, del que que en algunos tramos sólo se detectaron las zanjas de saqueo de sillares. En las hiladas superiores de la cimentación se aprecia, como en Santa Clara, un sistema constructivo "mediante encofrado de piedras calizas de mediano tamaño, trabadas con mortero de cal, arena y alguna grava, que alterna con sillares puestos a tizón. Este segundo tramo presenta una altura de $58 \mathrm{~cm}$ y un ancho de $75 \mathrm{~cm}$ " (Luna y Zamorano 1999: 150). El alzado de los muros del patio, los mejor conservados, con una anchura media de $0,75 \mathrm{~m}$, se realiza con este tipo de aparejo mixto, que "consiste en la alternancia de tramos de sillares - dos sillares colocados a soga con un módulo de $1,1 \times 0,35$ x 0,6 m y trabados con mortero de cal - con tramos de encofrado de mampuesto de piedras calizas de mediano tamaño trabadas con mortero de cal, arena y gravas" (Luna y Zamorano 1999: 150) (Fig. $13 \mathrm{~d}$ y e). Mientras que en los lienzos perimetrales se emplea esta técnica mixta, las estructuras de mayor relevancia arquitectónica e ideológica (contrafuertes que flanquean las puertas, mihrab y alminar) se levantan íntegramente en sillería, lo que demuestra una selección de materiales y técnicas dentro de un mismo edificio.

El ejemplo más destacado de este tipo de aparejo se localiza en esta ocasión en el espacio intramuros, en las inmediaciones del complejo palatino del alcázar andalusí. En la intervención arqueológica de urgencia realizada en 2002 en la sede del actual Centro de Arte Contemporáneo de la Fundación Botí (C/ Calle Manríquez, 5, junto a la Plaza Judá-Lévi) se documentó en el lateral sur del solar una potente estructura adscrita a época califal (Cano 2002: 65$)^{27}$ que en la actualidad se conserva integrado en los sótanos del edificio. Este muro, que se extiende por una longitud de más de diez metros, con una altura conservada de unos tres metros (incluida la zapata de cimentación) y con una anchura de $0,75 \mathrm{~m}$, está realizado con grandes sillares de calcarenita dispuestos a soga, con algunas piezas a tizón, que alternaban con rellenos intermedios cuadrados de mampostería bien careada, con piezas de calcarenita y piedra rojiza pizarrosa, trabada con abundante cal (Fig. 14a). Los paramentos documentados durante el seguimiento de la obra conservan en muy buenas condiciones el grueso llagueado de los tramos rellenos de mampostería, prácticamente cubiertos en su totalidad por el mortero de cal (Fig. 14b). La entidad de esta estructura, que se extiende más allá de los límites del solar y que marca la alineación de las construcciones

\footnotetext{
27 Cano Montero, J. I. 2002: Intervención Arqueológica de Urgencia C/ Manríquez, $n^{\circ}$ 5-7, Córdoba. Informe preliminar. Informe inédito. Córdoba.
}

posteriores, que la reutilizan y recrecen, y su ubicación junto al principal centro de poder político de la capital omeya permiten interpretar con bastante seguridad el carácter público u oficial de esta estructura. La cronología califal de esta construcción está abalada por la secuencia estratigráfica y los materiales asociados. El muro aparece asociado a un pavimento hidráulico de mortero de cal pintado a la almagra, bajo el cual se han documentado varios estratos de los que se han recuperado algunos fragmentos cerámicos "entre los cuales aparecen algunos fragmentos vidriados y cerámica pintada claramente islámicos, que nos hacen pensar en una cronología califal para la construcción de dicho muro, pese a la aparente ausencia de cerámica verde-manganeso" (Cano 2002: 66).

Esta atinada adscripción cronológica viene reforzada por las estrechas analogías que muestra con uno de los aparejos empleados en Madinat al-Zahra ${ }^{28}$ para levantar el muro que separa el área situada entre la "Plaza de Armas" y el sector del baño privado. Esta estructura, de la que es visible con más claridad su paramento oeste (pues la cara oriental está prácticamente oculta por estructuras adosadas con posterioridad y por restauraciones acometidas por Félix Hernández), está levantada con un singular aparejo en el que alterna la conocida disposición de los sillares a soga y tizón, con algunos bloques dispuestos a tabla, y rellenos cuadrangulares de mampostería formada por bloques de roca volcánica ${ }^{29}$ de color morado trabados con mortero con abundante cal (Fig. 14c). Con ello se consigue un curioso efecto cromático con la combinación de tonos claros de los sillares y oscuros de los mampuestos. No obstante, estos paramentos debieron quedar cubiertos originalmente por los revestimientos de mortero que protegían los materiales de los agentes atmosféricos, como ya hemos visto en el ejemplo de Córdoba. La reciente intervención arqueológica realizada por Félix Arnold ha permitido establecer una secuencia evolutiva del sector occidental de la Plaza de Armas, en la cual este muro pertenecería a las fases inciales; es decir, formaría parte de las primeras construcciones de la ciudad ${ }^{30}$.

\footnotetext{
28 Agradezco al director del Conjunto Arqueológico, D. Alberto Montejo, la información inédita y la posibilidad de fotografiar estas estructuras.

29 Este tipo de roca, denominada "piedra de montaña", forma parte del substrato geológico en el que se construye la ciudad califal, por lo que constituye un material abundante extraído para la explanación y aterrazamiento del terreno. Este material es utilizado para componer los pavimentos de las calzadas de acceso a la ciudad, en los que alternan con bloques de sillería (Vallejo 2010: 103 y 104).

30 Estos datos han sido facilitados por Félix Arnold, a quien agradecemos la información.
} 

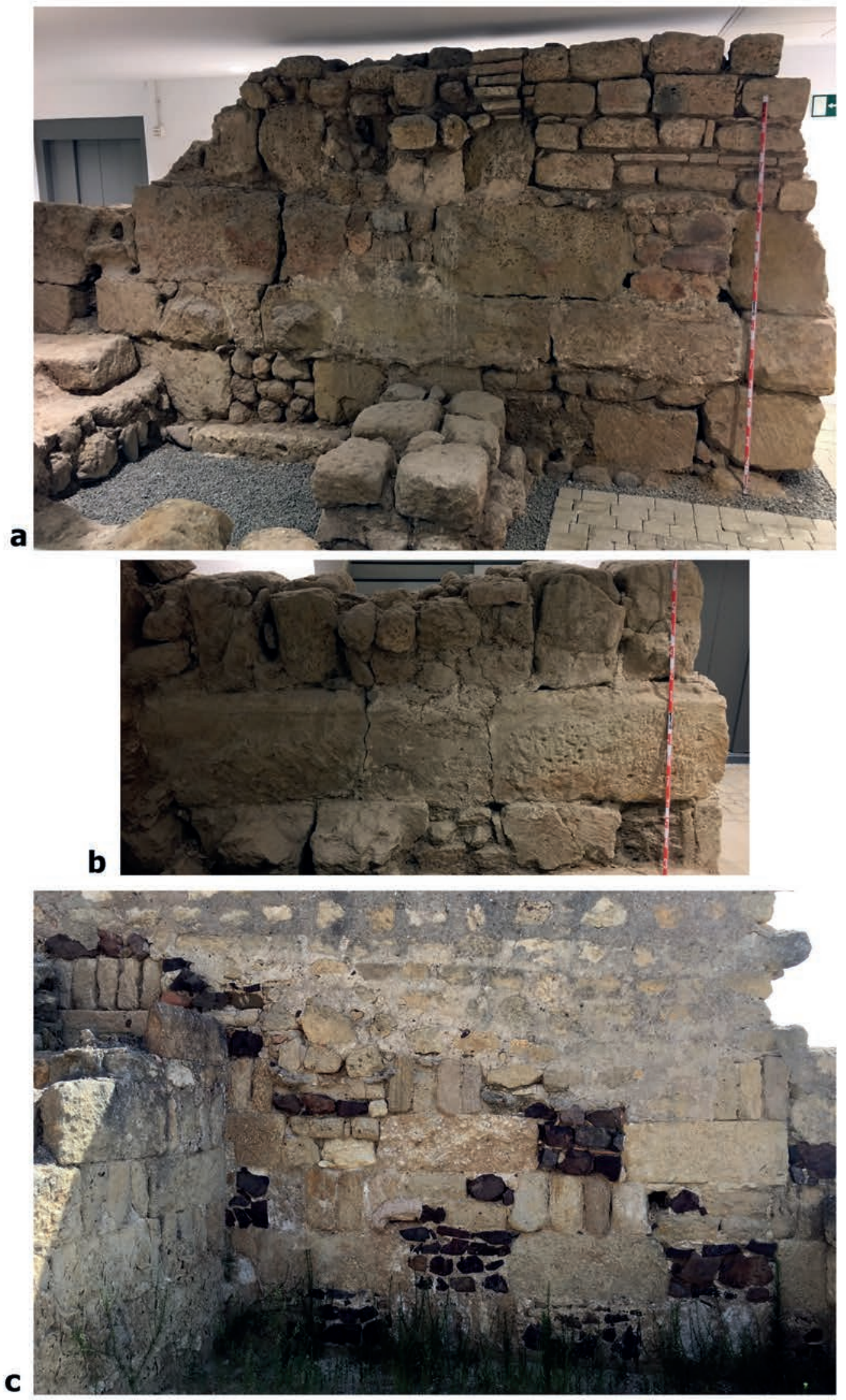

Figura 14. Aparejos en damero de época califal en Córdoba: a y b.- Centro de Arte Contemporáneo de la Fundación Botí (C/ Calle Manríquez, 5 , junto a la Plaza Judá-Lévi) (fotografías del autor); c: Madinat al-Zahra (fotografía del autor). 
En definitiva, a lo largo del siglo $\mathrm{X}$ se mantienen los mismos recursos técnicos empleados en época emiral, con el objetivo de reducir los costes en la construcción de los ambiciosos programas arquitectónicos acometidos por las autoridades califales, en especial, en aquellas estructuras que requieren un gran volumen de material pétreo. Sin embargo, la aplicación de estas técnicas mixtas no menguan en absoluto la calidad del resultado final, rematado con un cuidado revestimiento que cubre la fábrica y la protege de la afección de los agentes atmosféricos.

El único ejemplo que hemos podido identificar de este tipo de aparejo omeya fuera de Córdoba se encuentra en uno de los paramentos internos de la muralla califal de Ceuta, donde Pedro Gurriarán ha identificado un lienzo formado por una "fábrica mixta formada por tizones y cajas de mampostería que ocupan el hueco que deberían ocupar las sogas" (Gurriarán 2018: 421-422)31. Dicho paño, según el mismo autor, estaría soterrado y su singular aparejo no sería el resultado del expolio selectivo de las sogas, sino que formaría parte del mismo proceso constructivo de las defensas de la medina ceutí. En este caso, la particularidad con respecto a los aparejos de la capital andalusí antes expuestos es que las cajas de mampuestos ocupan el lugar de las sogas y no el de los tizones, como vemos en Córdoba.

Una fábrica poco habitual, en este caso en su cara intramuros que formaría parte del mismo impulso constructor del resto del lienzo omeya. Mientras que el frente exterior se erige con sogas y tizones canónicos, en el paramento interior aparece una fábrica mixta formada por tizones y cajas de mampostería que ocupan el hueco que deberían ocupar las sogas. No se trata del resultado del expolio y sustitución de esas últimas piezas, siempre más fáciles de extraer, como vemos en el lienzo norte del recinto ceutí o en el castillo de Tarifa, sino que esta organización es producto de una misma actuación. Esa parte de la muralla estaría soterrada, ya que la cota intramuros se situaría más alta que la exterior.

\section{CONCLUSIONES}

De este recorrido por los aparejos mixtos en piedra desde la Antigüedad Tardía hasta el final del Califato

\footnotetext{
31 Agradezco al Dr. Pedro Gurriarán la posibilidad de utilizar su Tesis doctoral, un trabajo de consulta obligada sobre las técnicas constructivas omeyas en al-Ándalus.
}

omeya de Córdoba se deducen algunas conclusiones provisionales que deberán ser confirmadas por estudios específicos futuros.

A pesar de la combinación de materiales que, en algún caso, pudiera hacer pensar en una cierta irregularidad de las estructuras resultantes, por lo general, los aparejos mixtos analizados de época omeya se emplean para la construcción de muros de gran entidad, potencia y longitud, como los asociados a obras de infraestructuras, para la contención de rellenos, o los destinados al cierre de grandes propiedades agropecuarias suburbanas (almunias), o ciertos elementos rectores del urbanismo, como muros maestros, fachadas de edificios, etc. La utilización de estos aparejos mixtos en edificios del entorno del poder omeya en la capital de al-Ándalus no debe ser entendido como una incapacidad técnica para levantarlos íntegramente en sillería, pues, como hemos visto, las principales construcciones desde finales del siglo VIII empleaban este material con total solvencia. Es más probable que su uso responda a la dificultad para abastecer de sillares desde las canteras próximas la creciente demanda para levantar los numerosos edificios que empezaron a poblar el entorno de la ciudad, con los que se estaba generando un paisaje urbano en proceso de islamización, en el que palacios (almunias), mezquitas y baños promovidos como obras pías resultaban elementos esenciales. En todos ellos es necesario un ingente volumen de material pétreo, por lo que se recurre a procedimientos conocidos en la tradición arquitectónica previa, como el uso recurrente de material de acarreo y su alternancia con la mampostería, que permiten dosificar y optimizar el uso de bloques de sillería, manteniendo la consistencia y monumentalidad de las construcciones, pero reduciendo significativamente los costes. De ahí que sea habitual encontrar la combinación de muros realizados con estos aparejos con otros levantados íntegramente en sillería a soga y tizón. Cuando el estado de conservación de las estructuras documentadas lo permite, se aprecia el cuidado tratamiento de estas construcciones en las que se suelen utilizar morteros de cal, e incluso encofrados, para trabar los rellenos de mampuestos, por lo general bien careados y dispuestos de forma ordenada. Con ello se logra la regularidad y estabilidad de los cajones de sillería que son los que, a la postre, sustentan la estructura. El resultado final no debería verse necesariamente afectado, al menos en lo relativo a su imagen exterior, pues, al igual que sucede con las principales obras oficiales hechas íntegramente en sillería (mezquita aljama, alcázar andalusí, Madinat 
al-Zahra, etc.), los muros estuvieron cubiertos por revestimientos de mortero que, incluso, simulaban el aparejo de sillería. Por tanto, podríamos afirmar que fueron considerados aparejos nobles o de prestigio, aunque se reserva el uso exclusivo de la sillería para elementos singulares de especial valor simbólico (como torres, contrafuertes y puertas en las almunias y alminares, mihrab-s o muros de quibla en las mezquitas).

Los ejemplos cordobeses mencionados, para los que hemos rastreado algunos paralelos en otras zonas de al-Ándalus, y el amplio repertorio de técnicas mixtas en Mérida, precisamente en edificios vinculados con los representantes de la autoridad omeya, parecen demostrar que no se trata de una singularidad o endemismo constructivo de la capital andalusí, aunque, lógicamente, el elenco pueda resultar más llamativo por la cantidad y calidad de las obras promovidas por la aristocracia omeya.

Aunque el repertorio que hemos recopilado no es exhaustivo, se constata que las técnicas mixtas en piedra tienen una significativa presencia en la arquitectura de prestigio de la capital omeya andalusí, en especial de época emiral, mucho más extendida de lo que se consideraba hasta ahora. Como hemos recogido en este trabajo, existen claros precedentes en construcciones públicas de época tardoantigua, asociadas habitualmente a edificios de prestigio, como los que consideramos integrados en el complejo episcopal o en hipotéticos centros de culto cristianos. Estos datos permiten aproximarnos al problema historiográfico de la procedencia, innovación y dependencias de las técnicas constructivas en piedra del mundo andalusí respecto de los precedentes tardoantiguos. Por lo que respecta al empleo de la sillería, es una cuestión que aún no tiene una respuesta unívoca en la investigación, pues se sigue discutiendo acerca de la atribución cronológica de muchas de las construcciones que protagonizan el debate. Sin embargo, en el caso de los aparejos mixtos consideramos que sí es posible considerar una clara continuidad y dependencia con respecto a los procedimientos constructivos y recursos técnicos precedentes en la península ibérica. En este sentido resultan de interés las consideraciones en relación con las técnicas constructivas empleadas en los edificios omeyas de Mérida, donde "la ambigüedad de la arquitectura emiral se debe, por un lado, a que hay continuidad de rasgos constructivos en materiales y aparejos que fácilmente pueden ser trasvasados a etapas más antiguas" (Alba 2009: 393). De hecho, las similitudes formales entre fábricas realizadas con aparejos mixtos de época tardoantigua e islámica dan pie a dudosas atribuciones cronológicas, en una etapa en la que son constantes las transferencias e influencias técnicas y culturales en la península ibérica. Por ese motivo hemos intentado aquilatar al máximo posible la datación de las diferentes estructuras expuestas en este estudio, para evitar caer en asignaciones cronológicas basadas exclusivamente en criterios formales. El objetivo a medio plazo será construir cronotipologías fiables; pero, de momento, el empleo de una determinada técnica constructiva no puede ser utilizado como único argumento cronológico por sí mismo para la datación de los edificios. Con este trabajo hemos pretendido, al menos, dar un primer paso en esta dirección.

\section{TABLAS CRONOTIPOLÓGICAS}

Tabla 1. ÉPOCA TARDOANTIGUA

\begin{tabular}{|c|c|c|c|c|}
\hline TIPO & UBICACIÓN & CRONOLOGÍA & $\begin{array}{l}\text { ARGUMENTACIÓN } \\
\text { CRONOLÓGICA }\end{array}$ & EDIFICIO \\
\hline pseudo opus africanum & Puerta del Puente & $\begin{array}{l}\text { finales del siglo VI y } \\
\text { siglo VII }\end{array}$ & estratigrafía y materiales & público (¿religioso?) \\
\hline opus africanum & anfiteatro romano & mediados del siglo IV & estratigrafía y materiales & público (¿religioso?) \\
\hline pseudo opus africanum & graderío del teatro & primera $1 / 2$ siglo VII & estratigrafía & público (aterrazamiento) \\
\hline pseudo damero & Ronda de Isasa, $n^{\circ} 4$ & siglo VI-VII & estratigrafía & ¿? \\
\hline pseudo opus africanum & Avda. Llanos del Pretorio & $\begin{array}{l}\text { fase } \\
\text { bajoimperial-tardoantigua }\end{array}$ & estratigrafía & ¿? \\
\hline opus africanum & Manzana 14 Plan Parcial O-7 & "en torno al siglo VI" & estratigrafía & público (¿religioso?) \\
\hline $\begin{array}{l}\text { mampostería reforzada } \\
\text { con grandes sillares } \\
\text { encadenados }\end{array}$ & Parque Infantil de Tráfico & siglos V y VI d.C. & estratigrafía y materiales & público (¿religioso?) \\
\hline
\end{tabular}


Tabla 2. ÉPOCA EMIRAL

\begin{tabular}{|c|c|c|c|c|}
\hline TIPO & UBICACIÓN & CRONOLOGÍA & $\begin{array}{l}\text { ARGUMENTACIÓN } \\
\text { CRONOLÓGICA }\end{array}$ & EDIFICIO \\
\hline $\begin{array}{l}\text { mampostería que alterna sin } \\
\text { un ritmo regular con bloques } \\
\text { de sillería reutilizadas }\end{array}$ & $\begin{array}{l}\text { Mid'a de la mezquita } \\
\text { aljama }\end{array}$ & $\begin{array}{l}\text { Emirato de Hisam I } \\
\text { (788-796) }\end{array}$ & datos históricos & $\begin{array}{l}\text { público religioso } \\
\text { mid'a }\end{array}$ \\
\hline $\begin{array}{l}\text { paramentos externos de } \\
\text { sillería e internos de opus } \\
\text { aficanum }\end{array}$ & al-rasif & $\begin{array}{l}\text { época del emir Abd al- } \\
\text { Rahman II (827-828) }\end{array}$ & $\begin{array}{l}\text { referencias textuales datos } \\
\text { históricos, estratigrafía y } \\
\text { materiales }\end{array}$ & público / oficial \\
\hline $\begin{array}{l}\text { paramentos externos } \\
\text { de sillería e internos de } \\
\text { mampostería }\end{array}$ & $\begin{array}{l}\text { "Patio de Mujeres" del } \\
\text { Alcázar }\end{array}$ & $\begin{array}{l}\text { época del emir Abd al- } \\
\text { Rahman II }\end{array}$ & $\begin{array}{l}\text { datos históricos, } \\
\text { estratigrafía y materiales }\end{array}$ & público / oficial \\
\hline opus africanum & $\begin{array}{l}\text { Zoológico Municipal de } \\
\text { Córdoba }\end{array}$ & siglo IX & estratigrafía y materiales & $\begin{array}{l}\text { almunia ¿Balat } \\
\text { Mughit? }\end{array}$ \\
\hline opus africanum & Hospital La Arruzafa & siglo IX & estratigrafía & almunia \\
\hline opus africanum & C/ Albéniz, $n^{\circ} 2$ & siglo IX & estratigrafía y materiales & ¿? \\
\hline opus africanum & $\mathrm{C} /$ Antonio del Castillo, $\mathrm{n}^{\circ} 3$ & época emiral & estratigrafía y materiales & ¿residencial? fachada \\
\hline opus africanum & Garaje Alcázar & ¿época emiral? & estratigrafia & muralla \\
\hline damero & Zona Tablero Bajo & ¿siglo IX? & tipología & almunia ¿al-Rusafa? \\
\hline damero & Parcela 2 del PPO7 & emiral (siglo IX) & estratigrafía & ámbito residencial \\
\hline damero & $\begin{array}{l}\text { naves municipales zona de } \\
\text { Fontanar de Cábanos }\end{array}$ & emiral (siglo IX) & estratigrafía & almunia \\
\hline damero & $\begin{array}{l}\text { Parcela 16A del Plan Parcial } \\
\text { PPO7 }\end{array}$ & emiral (¿siglo IX?) & estratigrafía & ¿almunia? \\
\hline opus africanum & $\begin{array}{l}\text { C/ Secretario Carretero, } \\
\text { esquina con } \mathrm{C} / \text { Antonio } \\
\text { Maura }\end{array}$ & almohade (siglo XII) & estratigrafía y materiales & ámbito doméstico \\
\hline
\end{tabular}

Tabla 3. ÉPOCA CALIFAL

\begin{tabular}{|l|l|l|l|l|}
\hline \multicolumn{1}{|c|}{ TIPO } & \multicolumn{1}{|c|}{ UBICACIÓN } & \multicolumn{1}{|c|}{ CRONOLOGÍA } & $\begin{array}{c}\text { ARGUMENTACIÓN } \\
\text { CRONOLÓGICA }\end{array}$ & \multicolumn{1}{c|}{ EDIFICIO } \\
\hline opus africanum & $\begin{array}{l}\text { Parcela 1.1. F3 de la } \\
\text { Avda. de Libia }\end{array}$ & siglo X & $\begin{array}{l}\text { ialmunia? Muro de deli- } \\
\text { mitación de una propie- } \\
\text { dad privada }\end{array}$ \\
\hline pseudo opus africanum & almunia de al-Rumaniyya y materiales & Califato de Al-Hakam II & referencias textuales & almunia \\
\hline ¿pseudo opus africanum? & C/ Músico Infantas, 1 & siglo X & iestratigrafía? & ámbito residencial \\
\hline ¿pseudo opus africanum $?$ & $\begin{array}{l}\text { carretera de Santa María } \\
\text { de Trassierra y la Avenida } \\
\text { Cañito Bazán }\end{array}$ & siglo X & iestratigrafía? & ialmunia? \\
\hline damero & $\begin{array}{l}\text { mezquita antiguo conven- } \\
\text { to de Santa Clara, }\end{array}$ & finales del siglo X & $\begin{array}{l}\text { estratigrafía y tipología } \\
\text { arquitectónica }\end{array}$ & mezquita \\
\hline damero & $\begin{array}{l}\text { Parcela 16A del Plan Par- } \\
\text { cial PPO7 }\end{array}$ & siglo X & estratigrafía & $\begin{array}{l}\text { ¿almunia? Ámbito } \\
\text { residencial }\end{array}$ \\
\hline ¿pseudo damero? & Estación de autobuses & siglo X & estratigrafía y materiales & ámbito residencial \\
\hline damero & mezquita de Fontanar & siglo X & estratigrafía y materiales & mezquita \\
\hline damero & $\begin{array}{l}\text { Centro de Arte Contem- } \\
\text { poráneo Fundación Botí } \\
\text { C/ Calle Manríquez, 5 }\end{array}$ & siglo X & estratigrafía y materiales & iámbito residencial? \\
\hline damero & Madinat al-Zahra & primera mitad del siglo X & $\begin{array}{l}\text { referencias textuales } \\
\text { estratigrafía }\end{array}$ & conjunto palatino \\
\hline
\end{tabular}




\section{BIBLIOGRAFÍA}

Adam, J.- P. 1996: La construcción romana: materiales y técnicas. León.

Alba Calzado, M. 2009: "Los edificios emirales de Morería (Mérida), una muestra de arquitectura del poder", Anales de Arqueología Cordobesa, 20, pp. 379-420.

Azuar, R. 1995: "Las técnicas constructivas en al-Andalus. El origen de la sillería y del hormigón de tapial", V Semana de Estudios Medievales, pp. 125-142.

Azuar, R. 2005: "Las técnicas constructivas en la formación de al-Andalus", Arqueología de la Arquitectura, 4, pp. 149-160.

Beltrán de Heredia, J. 2016: “Arqueología y técnicas constructivas en Barcelona: nuevos datos para el horizonte tardoantiguo", QuarHis, 12, pp. 58-77.

Beltrán de Heredia, J. y Macías i Solé, J. M. 2016: “Técnicas constructivas en la Tarraconensis durante la Antigüedad Tardía. Planteamientos y estrategias de investigación para una propuesta de síntesis", QuarHis, 12, pp. 16-38.

Caballero Zoreda, L. 2009: "Reflexiones a partir del estudio de aparejos constructivos Altomedievales”, en A. Suárez Márquez (ed.), Construir en al-Andalus: actas de las Jornadas Técnicas del Conjunto Monumental de la Alcazaba (Almería 2007), pp. 141-172. Sevilla.

Caballero Zoreda, L. y Utrero Agudo, M. Á. 2005: "Una aproximación a las técnicas constructivas de la Alta Edad Media en la Península Ibérica. Entre visigodos y omeyas", Arqueología de la Arquitectura, 4, pp. 169-192.

Caballero Zoreda, L. y Utrero Agudo, M. Á. 2013: "El ciclo constructivo de la Alta Edad Media Hispánica”, Archeologia dell'Architettura XVIII, Tecniche costruttive e cicli edilizi tra VI e IX secolo, fra Oriente e occidente, pp. 127-146.

Cánovas Ubera, A. y Sánchez Madrid, S. 2009: "Intervención Arqueológica Preventiva en la nueva sede de EMACSA (Avda. Llanos del Pretorio, Córdoba)", Anuario Arqueológico de Andalucía 2004, t. III, pp. 837-849.

Carmona Berenguer, S. 1997: "Casa con pórtico de época califal en el arrabal occidental de Córdoba", Anales de Arqueología Cordobesa, 8, pp. 213-228.

Casal García, M. a T. 2008: "Características generales del urbanismo cordobés de la primera etapa emiral: el arrabal de Saqunda”, Anejos de Anales de Arqueología Cordobesa, 1, pp. 109-103.

Casal García, M. ${ }^{a}$ T. y Salinas Pleguezuelo, M. ${ }^{\text {a }}$ E. 2009: "Informe-Memoria de la I. A. U. en la Puerta del Puente y en la Parcela Catastral 36394/09”, Anuario Arqueológico de Andalucía 2004, 1, pp. 711-722.

Castillo Pérez de Siles, F. 2008: "Un arrabal Almohade en la c/ Antonio Maura de Córdoba", en J. P. Bernardes (ed.), Actas do IV Congresso de Arqueologia Peninsular, Faro setembro 2004, pp. 63-76. Faro.

Castro, E., Pizarro, G. y Sánchez, I. 2006: "El conjunto arqueológico del Parque Infantil de Tráfico de Córdoba. La ocupación tardoantigua del suburbium occidental de Colonia Patricia Corduba", Anales de Arqueología Cordobesa, 17, vol. II, pp. 103-118.

Clapés Salmoral, R. 2013: "Un baño privado en el arrabal occidental de Madinat Qurtuba", Arqueología y Territorio Medieval, 20, pp. 97-128.

Díaz García, M. y Roig Perez, J. F. 2016: "Els edificis portuaris tardoantics de l'Area Fluvial de Tarraco i les seves técniques constructives", QuarHis, 12 , pp. 78-92.

Espada Belmonte, J. A. 2011: "El interrogante medioevo en Coria", I-II Jornadas de Arqueología e Historia medieval. La Marca Inferior de alAndalus, Mérida, pp. 57-80.

Gómez Martínez, S. 2011: "Intervenção Arqueológica na Mesquita-Igreja Matriz de Mértola", en S. Macias et alii, Mesquita Igreja de Mértola, pp. 89-104. Mértola.

González Gutiérrez, C. 2016: Las mezquitas de Córdoba: concepto, tipología y función urbana. Tesis doctoral. Córdoba. [En línea] http://helvia.uco.es/ handle/10396/13194

Gurriarán, P. 2004: "Hacia una construcción del poder. Las prácticas edilicias en la periferia andalusí durante el califato", Cuadernos de Madinat alZahra, 5, pp. 297-325.

Gurriarán, P. 2008: "Una arquitectura para el Califato: poder y construcción en al-Andalus durante el siglo X", Anales de Arqueología Cordobesa, 19, p. 266.
Gurriarán, P. 2014: "Las técnicas constructivas en las fortificaciones andalusíes”, en F. Sabaté y J. Brufal (dirs.), Arqueologia Medieval: La ciutat, Agira VI, pp. 299-328.

Hernández Jiménez, F. 1975: El alminar de Abd al-Rahman III en la mezquita mayor de Córdoba. Génesis y repercusiones. Granada.

Hidalgo Prieto, R. 2012: "Sobre el supuesto centro de culto cristiano del anfiteatro de Córdoba", Habis, 43, pp. 249-274.

Ibn Hayyan 2001: Crónica de los emires Alhakam I y Abdarrahmen II entre los años 796 y 847 [Almuqtabis II-1]. Zaragoza. [Traducción, notas e índices de M. 'Ali Makki y F. Corriente].

Lafuente y Alcántara, E. 1867: Ajbar Machmuá. Crónica anónima del siglo $X I$. Madrid.

León, A. 2003: Las fortalezas de Belalcázar (Córdoba). Análisis Arqueológico de su arquitectura (ss. IX-XIX). Córdoba.

León, A. 2006: "Pervivencias de elementos clásicos en la Córdoba islámica", en D. Vaquerizo y J. F. Murillo (eds.), El concepto de lo provincial en el mundo antiguo, vol. II, pp. 409-438. Córdoba.

León, A. 2008: "La construcción en sillería en España durante la Alta Edad Media. Una revisión de la información arqueológica”, Archeologia Medievale, XXXV, pp. 55-74.

León, A. (en prensa): "La técnica de la piedra en el primer recinto del Alcázar de Sevilla en el contexto de al-Andalus", en M. A. Tabales (ed.), El origen del alcázar de Sevilla. Estudios arqueológicos y constructivos (en prensa).

León, A. y Blanco, R. 2010: “La fitna y sus consecuencias. La revitalización urbana de Córdoba en época almohade", en D. Vaquerizo y J. F. Murillo (eds.), El Anfiteatro Romano de Córdoba y su entorno urbano. Análisis Arqueológico (ss. I-XIII d. C.), t. II, pp. 699-726. Córdoba.

León, A., León, E. y Murillo, J. F. 2008: “El Guadalquivir y las fortificaciones urbanas de Córdoba”, Las fortificaciones y el mar, IV Congreso Internacional sobre Fortificaciones, pp. 261-290. Alcalá de Guadaira.

León, A. y Murillo, J. F. 2009: "El complejo civil tardoantiguo de Córdoba y su continuidad en el Alcázar Omeya", Madrider Mitteilungen, 50, pp. 399-432.

Lopes, V. 2014: "Mértola na Antiguidade Tardia", Entre Roma e o Islão. Projecto de estudo e valorização do património da Antiguidade Tardia no Alentejo, pp. 138-165. Mértola.

Luna Osuna, M. a D. y Zamorano Arenas, A. 1999: "La mezquita de la antigua Finca «El Fontanar», (Córdoba)", Cuadernos de Madinat al-Zahra, 4, pp. 145-173.

Macías i Solé, J. M. 2014: "El territorio y la ciudad de Tarraco", en P. Pensabene y C. Sfameni (eds.), La villa restaurata e i nuovi studi sull'edilizia residenziale tardoantica, pp. 453-465. Bari.

Macías i Solé, J. M. 2015: "Tècniques constructives i arquitectura del poder al nord-est de la Tarraconense. Metodologia de representació dels procesos evolutius entre l'Alt Imperi i l'Antiguitat Tardana. Activitat duta a terme el 2013-2014", QuarHis, 11, pp. 201-214.

Malpica Cuello, A. 1998: "Las técnicas constructivas en al-Andalus. Un debate entre la arqueología y la arquitectura", Técnicas agrícolas, industriais e constructivas na Idade Media (curso de verán, Celanova, 8-12 de xullo de 1996), pp. 277-336. Vigo.

Marfil Ruiz, P. 1999: “Avance de resultados del estudio arqueológico de la fachada este del oratorio de Abd al-Rahman I en la mezquita de Córdoba", Cuadernos de Madinat al-Zahra, 4, pp. 175-207.

Marfil, R. 2002: “Antigua iglesia del convento de Santa Clara”, Córdoba, Cordvba, Qurtuba. Patrimonio de la Humanidad, Diario Córdoba, pp. 249-272. Córdoba.

Martí, J. y Pascual, J. 2000: "El desarrollo urbano de Madīna Balansiya hasta el final del califato", en L. Cara (ed.), Ciudad y Territorio en al-Andalus, pp. 500-536. Granada.

Martín Urdíroz, I. 2006: "Informe-Memoria de la I. A. U. en el recinto de los hipopótamos del Zoológico Municipal de Córdoba", Anuario Arqueológico de Andalucía 2003, vol. I, pp. 397-410. Sevilla.

Monterroso, A. J y Cepillo, J. J. 2002: "La ocupación medieval", en A. Ventura et alii (eds.), El teatro romano de Córdoba. Catálogo de la exposición, pp. 161-172. Córdoba.

Murillo Redondo, J. F. 2009: "La almunia de al-Rusafa en Córdoba", Madrider Mitteilungen, 50, pp. 449-482. 
Murillo Redondo, J. F. et alii. 2009-2010: "Investigaciones arqueológicas en la Muralla de la Huerta del Alcázar (Córdoba)", Anejos de Anales de Arqueología Cordobesa, 2, pp. 183-230.

Murillo, J. F., Casal, M. ' T. y Castro, E. 2004: "Madinat Qurtuba. Aproximación el proceso de formación de la ciudad emiral y califal a partir de la información arqueológica", Cuadernos de Madinat al-Zahra, 5, pp. 257-290.

Navarro Palazón, J. y Jiménez Castillo, P. 2011: “Materiales y técnicas constructivas en la Murcia andalusí (siglos X-XIII)", Arqueología de la Arquitectura, 8, pp. 85-120. https://doi.org/10.3989/arqarqt.2011.10012

Ortiz Urbano, R. 2009: "Actividad Arqueológica Preventiva en C/ Albéniz, 2 (Córdoba)", Anuario Arqueológico de Andalucía 2004, vol. I, pp. 880-887. Sevilla.

Palomino Guerrero, D. 2009: “Actividad Arqueológica Preventiva en C/ Músico Infantas, 1 de Córdoba”, Anuario Arqueológico de Andalucía 2004, vol. I, pp. 888-897. Sevilla.

Pavón Maldonado, B. 1994: “Córdoba y los orígenes de la arquitectura hispanomusulmana. Aspectos técnicos", Boletín de la Real Academia de Córdoba, 127, pp. 269-341.

Pavón Maldonado, B. 1999: Tratado de arquitectura hispano-musulmana. II. Ciudades y Fortalezas. Madrid.

Penco Valenzuela, R. 2017: "Actividad Arqueológica Preventiva en la Parcela 1.1. F3 Avda. de Libia”, Anuario Arqueológico de Andalucía 2008, pp. 1671-1680. Córdoba.

Rodero Pérez, S. y Asensi Llácer, M. ${ }^{\mathrm{a}}$ J. 2006: "Un Sector de la expansión Occidental de la Córdoba islámica: el arrabal de la Carretera de Trassierra (II). Sector Central”, Romula, 5, pp. 295-336.

Rodero Pérez, S. y Molina Mahedero, J. A. 2006: "Un Sector de la expansión Occidental de la Córdoba islámica: el arrabal de la Carretera de Trassierra (I)", Romula, 5, pp. 219-294.

Ruiz Lara, M. ${ }^{\text {a }}$ D. et alii. 2008: "La ocupación diacrónica del 'Yanib al-Garbi de Qurtuba' (siglos VIII-XIII): intervenciones arqueológicas realizadas en el Zoológico Municipal de Córdoba. Análisis de conjunto", Anejos de Anales de Arqueología Cordobesa, 1, pp. 163-200.

Ruiz Nieto, E. 2009: "Intervención Arqueológica Preventiva en la C/ Antonio del Castillo, 3 (Córdoba)”, Anuario Arqueológico de Andalucía 2004, vol. I, pp. 1190-1195.

Ruiz Taboada, A. y Azcárraga Cámara, S. 2016: "Nuevos datos sobre el diseño urbano de Toletum: las cloacas de la Bajada del Barco", Gerion, vol. 34, pp. 249-287.

Sarabia Bautista, J. 2013: "El ciclo edilicio en la arquitectura tardoantigua y altomedieval del sureste de Hispania: los casos de Valentia, Eio y Carthago
Spartaria", Archeologia dell'Architettura XVIII, Tecniche costruttive e cicli edilizi tra VI e IX secolo, fra Oriente e occidente, pp. 147-170.

Tabales Rodríguez, M. A. 2000: "Algunas reflexiones sobre fábricas y cimentaciones sevillanas en el período islámico", en A. Graciani et alii (eds.), Actas del Tercer Congreso Nacional de Historia de la Construcción, Sevilla, 26-28 octubre 2000, pp. 1077-1088. Madrid.

Tabales Rodríguez, M. A. 2001: "Intervención Arqueológica en la Calle Imperial 41-45. Contribución al conocimiento de la transformación urbana del barrio de San Esteban de Sevilla", Anuario Arqueológico de Andalucía 1996, t. III, pp. 415-430. Sevilla.

Tabales Rodríguez, M. A. et alii. 2016: Análisis arqueológico del Alcázar de Sevilla II (2010-2015). Memoria Proyecto General de Investigación. Investigaciones arqueológicas en el Patio de Banderas 2010-2015, tomos I y II. Sevilla.

Vallejo Triano, A. 2010: La ciudad califal de Madinat al-Zahra. Arqueología de su arquitectura. Sevilla.

Vallejo Triano, A. y Fernández Barba, R. 2010: "Una aproximación a las canteras de piedra calcarenita de Madīnat al-Zahrā'”, Cuadernos de Madīnat al-Zahrā', 7, pp. 405-419.

Valor Piechotta, M. 1997: "Las defensas de Carmona", Archivo Hispalense, 243-244-245, pp. 597-635.

Valor Piechotta, M. 2014: "La muralla de Carmona en el contexto de las cercas urbanas del sur de Al-Andalus", en M. González, A. Caballos y J. A. Ruiz De la Rosa (eds.), Urbanismo, Arquitectura y Patrimonio en Carmona, Actas del IX Congreso de Historia de Carmona, pp. 187-197. Sevilla.

Vaquerizo, D. y Murillo, J. F. 2010: "Ciudad y suburbia en Corduba. Una visión diacrónica (siglos II a. C. - VII d. C.)”, en D. Vaquerizo (ed.), "Las áreas suburbanas en la ciudad histórica. Topografía, usos, función”, Monografias de Arqueología Cordobesa, 18, pp. 455-522. Córdoba.

Vargas Cantos, S. et alii. 2007: "Los contextos cerámicos tardoantiguos de un solar anexo a la Puerta del Puente (Córdoba)", en M. Bonifay y J. C. Tréglia (eds.), "LRCW 2. Late Roman Coarse Wares, Cooking Wares and amphorae in the Mediterranean: Archaeology and Archeometry", BAR International Series 1662 (I), pp. 165-176. Oxford.

Vargas Lorenzo, C. 2016: "Estudio cronotipológico-constructivo", en M. A. Tabales (dir.), Análisis arqueológico del Alcázar de Sevilla II (2010-2015), Memoria Proyecto General de Investigación, tomo II, pp. 1-30. Sevilla.

Vizcaíno Sánchez, J. 2007: La presencia bizantina en Hispania (siglos VIVII). La documentación arqueológica. Antigüedad y Cristianismo XXIV. Murcia. 